\title{
Chief Justice William Howard Taft's Conception of Judicial Integrity: The Legal History of Tumey v. Ohio
}

Joshua E. Kastenberg

University of New Mexico - School of Law

Follow this and additional works at: https://digitalrepository.unm.edu/law_facultyscholarship

Part of the Courts Commons, Judges Commons, and the Legal Ethics and Professional Responsibility Commons

\section{Recommended Citation}

Joshua E. Kastenberg, Chief Justice William Howard Taft's Conception of Judicial Integrity: The Legal History of Tumey v. Ohio, 65317 (2017).

Available at: https://digitalrepository.unm.edu/law_facultyscholarship/416

This Article is brought to you for free and open access by the UNM School of Law at UNM Digital Repository. It has been accepted for inclusion in Faculty Scholarship by an authorized administrator of UNM Digital Repository. For more information, please contact amywinter@unm.edu, Isloane@salud.unm.edu,sarahrk@unm.edu.

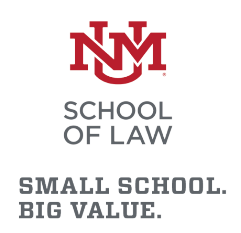

BIG VALUE. 


\title{
CHIEF JUSTICE WILLIAM HOWARD TAFT'S CONCEPTION OF JUDICIAL INTEGRITY: THE LEGAL HISTORY OF TUMEY V. OHIO
}

\author{
JOSHUA KASTENBERG*
}

ABSTRACT

In 1927, Chief Justice William Howard Taft led a unanimous Court to determine that, at minimum, the right to an impartial and independent judiciary meant that the judge had to lack a personal interest in the outcome of the trial. While the decision, Tumey v. Ohio, was based on a judge's pecuniary interest, it was also part of Taft's efforts to ensure that the nation's judges, from the municipal courts to the Supreme Court had the public's confidence in their integrity. Tumey, therefore, is not simply a decision on pecuniary interests. It can, and should, be applied to judicial elections, including the financing of elections and limits on election speech, as well as a judge's association or relationships with the litigants.

\section{CONTENTS}

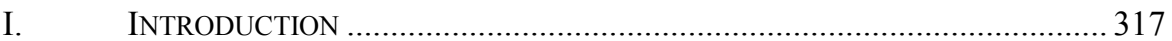

II. JUDICIAL AUTHORITY, IMPARTIALITY, AND DECORUM, ON THE EVE OF THE

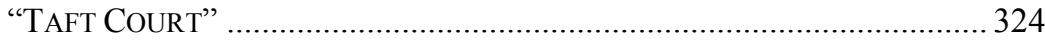

A. Berger v. United States ............................................................. 326

B. Judicial Biography ................................................................. 328

C. $\quad$ Taft and the Shaping of Judicial Governance............................... 337

III. THE “TAFT COURT” AND THE JUDICIAL CONTEMPT AUTHORITY ............. 341

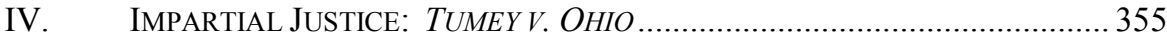

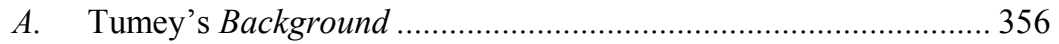

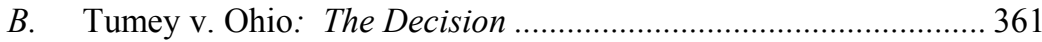

C. Kinship: The Taft Family............................................................... 369

V. CONCLUSION: CONTEMPORARY USE OF THE DECISION AND AN ARGUMENT FOR INCORPORATING JUDICIAL INTENT IN THE FUTURE.......................... 373

\section{INTRODUCTION}

On March 7, 1927, Chief Justice William Howard Taft wrote his younger brother Horace Taft, "I am going to deliver an opinion this morning in a very important alcohol prohibition act matter in Ohio." 1 Taft went on to explain that the Supreme Court's decision did not address whether the so-called Volstead Act, which implemented the Eighteenth Amendment, was constitutional, but rather it addressed how Ohio's system of prohibition enforcement violated due process. ${ }^{2}$ Ohio's legislature had enacted a

* Assistant Professor of Law, University of New Mexico School of Law.

1 Letter from William Howard Taft, Chief Justice, U.S. Supreme Court, to Horace Taft, Brother of Taft (Mar. 7, 1927) (on file in the Library of Congress).

2 U.S. CONST. amend. XVIII reads:

Section 1. After one year from the ratification of this article the manufacture, sale, or transportation of intoxicating liquors within, the importation thereof into, or the 
prohibition statute as an analog to the Volstead Act. ${ }^{3}$ Known as the "Crabbe Act," Ohio's law barred the possession of "intoxicating liquor." 4 After mailing his letter to his brother, Taft walked to the Supreme Court and assembled the Justices to announce the decision. Reported in newspapers across the country, the decision, captioned as Tumey v. Ohio, ${ }^{5}$ determined that Ohio's downward delegation of prohibition enforcement to municipal courts failed to ensure due process. ${ }^{6}$ One day before writing to Horace, Taft wrote to his son Charles Phelps Taft II that the Court had unanimously determined that the Crabbe Act was "invalid under the Fourteenth Amendment" and then stressed that the Justices found the Ohio law repugnant to fundamental rights. ${ }^{7}$

Tumey has become a benchmark for assessing judicial impartiality, but the legal history of the decision, including how it was shaped, has hardly been written about. Professor Robert Post, in an article titled "Federalism, Positive Law, and the Emergence of the American Administrative State: Prohibition in the Taft Court Era,"

exportation thereof from the United States and all the territory subject to the jurisdiction thereof for beverage purposes is hereby prohibited.

Section 2. The Congress and the several States shall have concurrent power to enforce this article by appropriate legislation.

Section 3. This article shall be inoperative unless it shall have been ratified as an amendment to the Constitution by the legislatures of the several States, as provided in the Constitution, within seven years from the date of the submission hereof to the States by the Congress.

For more information on the implementation of the Eighteenth Amendment into law, see National Prohibition Act of 1919, ch. 85, 41 Stat. 305. Although the National Prohibition Act, more commonly called the Volstead Act, implemented the Eighteenth Amendment, it further restricted prohibition by making possession of alcohol, with limited exceptions, unlawful. For more information on the constitutionality of the Volstead Act, see Rhode Island v. Palmer, 253 U.S. 350 (1920).

3 An Act to Prohibit the Liquor Traffic and to Provide for the Administration and Enforcement of Such Prohibition and Repeal Certain Sections of the General Code, ch. 108, OHIO Gen. CODE 6212-15 (1919). This provision barred the possession of "any intoxicating liquors" within the state. Id. See, e.g., Ruppert v. Caffrey, 251 U.S. 264, 284 (1920).

4 See, e.g., Decker v. State, 150 N.E. 74, 75 (Ohio 1925); Krusoczky v. State, 140 N.E. 614,615 (Ohio 1923). It appears through the available case law that the majority of prohibition violations in Ohio were not, under state law, dealt with as felonies, but rather were adjudicated in municipal courts where it was common for fines to be assessed. However, a person's failure to pay an adjudged fine could result in imprisonment.

5 Tumey v. Ohio, 273 U.S. 510 (1927).

6 See, e.g., Ohio Liquor Courts Declared Illegal; Supreme Court Rules Costs as Judges' Compensation Violates Constitution, N.Y. TIMES, Mar. 8, 1927, at 3; Highest Court Sounds Doom of Liquor Courts in Ohio, The CincinNATI EnquiRER, Mar. 8, 1927, at 1, 10; Judge Cannot Profit by Own Decisions: Chief Justice Taft Gives Opinion in Case of Ohio Mayor, Lewiston Sun (Maine), Mar. 8, 1927, at 1, 4; Ohio's Dry Law Hit by Supreme Court, PhILADELPHIA INQUIRER, Mar. 8, 1927, at 1.

7 Letter from William Howard Taft, Chief Justice, U.S. Supreme Court to Charles Phelps Taft II, son of William Howard Taft and Mayor, Cincinnati (Mar. 6, 1927) (on file in the Library of Congress). 
placed Tumey as part of the Court's authoritative — or "national" - expansion over the United States. ${ }^{8}$ Yet unlike decisions upholding Prohibition, Tumey placed restraints against its enforcement. Professor Post was not in error in analyzing Tumey in the context of Prohibition or the Court's authoritative expansion, but to exclusively do so results in an incomplete historic analysis of the judicial intent underlying the decision. For instance, Tumey arose during Taft's efforts to limit congressional attempts to govern the judiciary. ${ }^{9}$ The case was also decided at a time when Taft had been attacked as being beholden to corporate interests and therefore overly partial to wealthy litigants. ${ }^{10}$ Most importantly, Tumey was part of a line of cases and extrajudicial actions that Taft used to shape judicial ethics. A legal history centering on Taft's conception of the duties and independence of judges, as well as constraints on judicial power, amplifies how he led a largely conservative, yet jurisprudentially diverse, Court to unanimously intervene in a state's municipal court construct. While it may be correct, as legal historian Melvin Urofsky has pointed out, that during the period Taft sat as Chief Justice the justices limited their dissents in an effort to fend off Congressional efforts to narrow federal court jurisdiction, the justices did dissent in several appeals, particularly decisions involving criminal prosecutions. ${ }^{11}$ The unanimity underlying Tumey is also, in this light, a noteworthy element in analyzing Taft's intent.

Taft believed that Edward Tumey's appeal from an Ohio conviction and sentence of a fine provided an avenue to force upon the states a base-line uniformity of judicial ethics that would bolster public confidence in the nation's courts, including in its "inferior courts." $12 \mathrm{He}$ also intended that this judicially crafted "base-line" would be

8 Robert Post, Federalism, Positive Law, and the Emergence of the American Administrative State: Prohibition in the Taft Court Era, 48 YALE L. J. 1, 9 (2006).

9 See, e.g., Letter from James Beck, U.S. Representative, to William Howard Taft, Chief Justice, U.S. Supreme Court (Jan. 2, 1928) (on file in the Seeley G. Mudd Library at Princeton University). In this letter, Beck responds to Taft that he will work with the Chief Justice to defeat a measure initiated by Senator George Norris to limit the jurisdiction of the federal courts. It is clear from this letter that Taft encouraged Beck, a former Solicitor General of the United States and Republican Congressman to work to defeat Norris:

I have your kind letter of the 24th and you may be sure that, when the Norris Resolution comes up in the House, I will break my silence and have something to say about this attempt to destroy the Federal Courts.

I do not know the present state of the resolution, but I rather imagine it has been smothered in the Judiciary Committee. However, I will find out what the situation is when Congress reconvenes today.

Id.

10 Letter from George Norris, U.S. Senator, Neb., to Henrik Shipstead, U.S. Senator, Minn. (Dec. 7, 1922) (on file in the Library of Congress).

11 Melvin Urofsky, Louis D. Brandeis: A Life 578-79 (2009). According to another commentator, Taft had three priorities as Chief Justice: harmony, efficiency, and unanimity. "More than a clear docket, Taft wanted unanimous decisions." THE SUPREME CourT IN Conference, 1940-1985: The Private Discussions Behind Nearly 300 Supreme Court Decisions, 73-74 (Del Dickson ed., 2001) [hereinafter The Supreme Court IN Conference].

12 The Supreme Court in CONFERENCE, supra note 11, at 74-75. 
expanded over time as new challenges arose. In examining Taft's influence on the shaping of the judiciary, particularly during his tenure as chief justice, it becomes clear that Tumey should not be considered as simply a decision on the nexus between pecuniary interest and the public's right to an independent and impartial judiciary. Rather, Tumey should be considered as a key part of an effort to create a judiciary limited on power, respectful of legislative processes, and also to ensure a system of impartial tribunals from local courts of limited jurisdiction to the nation's highest court. Implicit in Taft's efforts was a related, if not intertwined, goal of shaping the judiciary so that the public placed confidence in it. However, as noted further below, Tumey was also a "family affair" which arose in the very geographic area that Taft and his family had obtained political prominence, and this too influenced the decision. ${ }^{13}$

The Court's grant of certiorari to Tumey's appeal was unique for several reasons. Notwithstanding the fact that during Taft's tenure the Court overturned state convictions based on the teaching of children in the German language in World War $\mathrm{I}$, and in one instance, it overturned a state trial court conviction based on a white-mob dominating a trial of African-American defendants, the Court had been historically reticent to apply the Fourteenth Amendment to state criminal trial procedures. ${ }^{14}$ As a sampling, in 1884 in Hurtado v. California, ${ }^{15}$ the Court determined that the Fourteenth Amendment did not mandate the Fifth Amendment's grand jury requirement in state felony trials. In 1900, in Maxwell v. Dow, ${ }^{16}$ the Court not only reaffirmed that the Fourteenth Amendment did not require a grand jury for a state felony prosecution to proceed, but also decided that the Constitution did not require state felony trials to

13 See infra Section I.B.

14 See, e.g., Mark Warren Bailey, Guardians of the Moral Order: The Legal Philosophy OF THE SuPREMe Court, 1860-1910, at 106-12 (2004); THE WARREN CourT IN Historical and Political Perspective 18-19 (Mark Tushnet ed., 1993); Henry J. Abraham, The Judiciary: The Supreme Court in the Governmental Process, 127-28 (Dorian M. Ring ed., 1991). The "German language teaching" cases are Meyer v. Nebraska, 262 U.S. 390 (1923), and Bartels v. Iowa, 262 U.S. 404 (1923).

In Moore v. Dempsey, 261 U.S. 86, 87, 92 (1923), the Court, in a decision authored by Justice Holmes, briefly discussed the facts asserted by counsel representing the five African American men who had been sentenced to death in two trials, but then determined that the Court would not take accept the facts underlying the trial, as part of its decision. Moore v. Dempsey, Rather, the Court sent the appeal back to the United States District Court to determine whether the state had taken "protective processes," to ensure the accused men had been afforded due process in both trials. Thus, while the Court upheld the principle articulated in Frank v. Magnum, 237 U.S. 309, 345 (1915), that a mob-dominated trial lacked due process, the Court in Moore did not specifically find that the trial on appeal had violated due process. Because of the decision's dearth of facts and analysis, Moore might only be tangentially part of Taft's conception of judicial ethics. Certainly, the trial judge could have barred the white mob from collecting near the court-room, but such an action was not discussed in Taft's correspondences nor that of the collections of the other justices.

15 Hurtado v. California, 110 U.S. 516, 553 (1884).

16 Maxwell v. Dow, 176 U.S. 581, 604-05 (1900). 
have twelve jurors as a minimum. ${ }^{17}$ Eight years later in Twining v. New Jersey, ${ }^{18}$ the Court determined that the Fifth Amendment's prohibition against compulsory selfincrimination did not preclude a state trial judge from instructing a jury that a defendant's decision to not testify in his own defense could be considered as evidence of guilt. ${ }^{19}$ This decision permitted juries in state criminal trials to consider a "negative inference" against a defendant that was unconstitutionally impermissible in federal criminal trials. Thus, if the Court were to overturn Tumey's conviction, and by implication Ohio's statutes and case law, the justices would, at a minimum, have to determine whether the Fourteenth Amendment required judicial impartiality in all of the nation's inferior courts that were administered by the states, counties, and municipalities. Unlike the appeals arising from convictions for teaching elementary school pupils in the German language, which had no federal criminal analog, Tumey was convicted of violating a nationwide offense that had been emplaced into the Constitution, albeit his conviction was prosecuted as a state crime. ${ }^{20}$

The Court and the lesser federal courts have consistently cited to Tumey since its issuance, but the judiciary's use of the decision appears to have buried its legal history into a few non-descript phrases. For instance, in 2015 in Williams-Yulee v. Florida Bar, ${ }^{21}$ Tumey is cited twice but only as a baseline in finding that a rule prohibiting a judicial candidate from directly soliciting potential donors was not unconstitutional. Writing for the majority, Chief Justice John Roberts observed, "The concept of public confidence in judicial integrity does not easily reduce to precise definition, nor does it lend itself to proof by documentary record. But no one denies that it is genuine and compelling." ${ }^{22}$ As noted throughout this Article, Taft linked public confidence to

17 Id. Justice Rufus Peckham, who authored the majority opinion, penned into the decision:

It appears to us that the questions whether a trial in criminal cases not capital shall be by a jury composed of eight instead of twelve jurors, and whether in case of an infamous crime a person shall only be liable to be tried after presentment or indictment of a twelve jurors, and whether in case of an determined by the citizens of each State for themselves, and do not come within the clause of the amendment under consideration, so long as all persons within the jurisdiction of the state are made liable to be proceeded against by the same kind of procedure and to have the same kind of trial, and the equal protection of the laws is secured to them.

Id. at 604. The Court's reasoning in Maxwell continued into the post-Warren Court era. For instance, in Apodaca v. Oregon, 406 U.S. 404, 411 (1972), and Johnson v. Louisiana, 406 U.S. 356, 363 (1972), the Court, in a decision authored by Justice Byron White, determined that the Fourteenth Amendment did not require unanimous juries in state criminal trials even though unanimous twelve member juries were required in federal criminal trials.

18 Twining v. New Jersey, 211 U.S. 78, 114 (1908). In Adamson v. California, the Court essentially reaffirmed that while in a federal court it would be unconstitutional to permit a jury to consider a defendant's silence or decision not to testify as evidence of guilt, the Fourteenth Amendment did not prohibit a state court from permitting a jury to consider such conduct. Adamson v. California, 332 U.S. 46, 59 (1947).

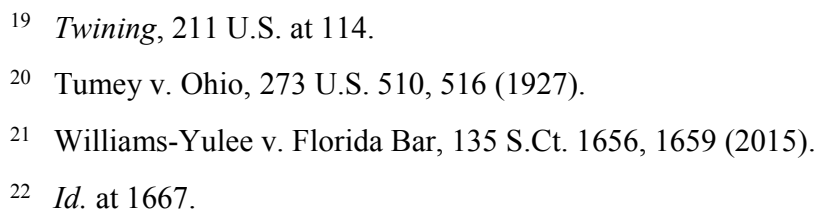


judicial integrity in his approach to Tumey. In Caperton v. A.T. Massey Co. ${ }^{23}$ the Court, in a decision authored by Justice Anthony Kennedy, determined that an elected state supreme court judge was constitutionally required to recuse himself where an appellant had donated over \$2 million to an organization which campaigned on behalf of the judge. The majority cited to Tumey as "the early and leading case on the subject" of judicial recusal and noted that the Court in Tumey was concerned "with more than the traditional common-law prohibition on direct pecuniary interest. ${ }^{24}$ It also was concerned with a more general concept of interests that tempt adjudicators to disregard neutrality." ${ }^{25}$ As noted below, while Taft would have agreed that Tumey prohibited a judge from having a direct pecuniary interest in case that he or she presided over, he certainly did not intend for the decision to serve as a ceiling on recusal. ${ }^{26}$ In Republican Party $v$. White, ${ }^{27}$ the Court, in a decision authored by Justice Antonin Scalia, determined that Minnesota's statutory restriction against judicial candidates expressing their opinions on "disputed legal or political issues" prior to an election, failed under the First Amendment's "strict scrutiny test." 28 In doing so, Justice Scalia and the majority implied that Tumey did not extend so far as restricting speech to the degree that Minnesota's statute known as the "announce clause" prevented, even if the statute was intended to enforce the perception of judicial impartiality. ${ }^{29}$ It is unlikely that Taft would have agreed with the majority's limitation of Tumey's applicability because, as noted throughout this Article, at times, and within limits, he disapproved of judges overtly engaging in politics. ${ }^{30}$ Taft believed that judges who engaged in overt political activity would have to recuse themselves from trials and appeals where they had earlier publicly articulated a view on an issue. ${ }^{31}$ Moreover, in the plain language of Tumey, it is clear that Taft intended for state legislatures to regulate their judicial branch to maximize public confidence in it. In short, the judicial intention underlying Tumey has been absent from the Court's recent jurisprudence and should be given new life.

With the recognition that the plain language of a decision is the paramount determination of what later decisions incorporate, a legal history of Tumey centering

23 Caperton v. A.T. Massey Co., 556 U.S. 868, 889-90 (2009).

24 Id. at 876,878 .

25 Id. at 878. For reasons noted in Section V, in particular Ohio v. Dugan, 277 U.S. 61, 63 (1928), the Court's interpretation of Tumey in Caperton, without more, is understandable.

26 See infra Section III.B.

27 Republican Party v. White, 536 U.S. 765, 768 (2002). Known as the "announce clause," Minnesota's law was designed to prohibit judicial candidates from promising outcomes in judicial decisions.

28 Id. at 772-73. The Court pointed out that the announce clause is a broader restriction than a prohibition against a judicial candidate promising to vote on a specific manner in a future litigation.

29 Id. at 776.

30 See infra Section I.A.

31 Id. 
on judicial intent should result in a broader use of the decision regarding judicial disqualification. ${ }^{32}$ This Article is divided into four sections.

Section I provides a short contextual overview of Prohibition as well as the "state" of judicial decorum and impartiality on the eve of Taft's ascension to the Chief Justiceship and thereby provides context for Taft's efforts. This section also includes a brief biography of Taft as well as the eight other justices serving on the Court at the time of Tumey. Section I also examines one decision, Berger v. United States, ${ }^{33}$ issued shortly before Taft's nomination, for its impact on Tumey.

Section II provides a brief overview of Taft's legislative efforts as well as his role in the formation of the American Bar Association's first ever issuance of a model set of judicial canons. This section also analyzes three significant Taft Court decisions on judicial authority, particularly in regards to the judiciary's contempt power. The three decisions, Craig v. Hecht, ${ }^{34}$ Cooke v. United States, ${ }^{35}$ and Ex Parte Grossman, ${ }^{36}$ not only provide context to Taft's theory of limited judicial authority, but also were part of a continuum leading to Tumey.

Section III describes Tumey's origins, including the backgrounds of the attorneys involved in the decision as well as the decision's state legal history leading to the grant of certiorari. This section also analyzes how far Taft intended the decision to reach. That is, it provides evidence that Taft intended Tumey to influence more than challenges based on direct pecuniary interest.

The conclusion, in Section IV, argues that while much of the past judicial use of Tumey is not in error - with the caveat that "overly narrow interpretation" and "not in error" are also not synonymous - there is a possible broader application for the decision than previously used in two areas. The first area involves challenges based on indirect pecuniary connections to a cause, and the second area encompasses challenges based on implied non-pecuniary interests in the outcome. Given that recent polling indicates a loss of public confidence in legal institutions, including the judiciary, (both the elected or appointed state judicial branches and the federal judiciary), a broader application of Tumey to disqualification would be consistent with Taft's goal of maintaining judicial integrity in both its real form and in perception. ${ }^{37}$ On this last point, there are two caveats: (1) this Article does not call for the abolishment of judicial elections; and (2) in focusing on the application of Tumey to recusal/disqualification cases, the focus necessarily bypasses a detailed constitutional analysis of efforts to curb judicial pre-election campaign speech.

32 See, e.g., United States v. Carver, 260 U.S. 482, 490 (1923); Maryland v. Baltimore Radio Show, 338 U.S. 912, 917 (1950).

33 Berger v. United States, 225 U.S. 22 (1921).

34 Craig v. Hecht, 263 U.S. 255 (1923).

35 Cooke v. United States, 267 U.S. 517 (1925).

36 Ex Parte Grossman, 267 U.S. 87 (1925).

37 As a poll sampling see, e.g., Jeffrey N. Jones, Trust in U.S. Judicial Branch Sinks to New Low of 53\%, GalluP POLL (Sept. 12, 2015); Billy Correher, Voters Overwhelmingly Support Judicial Election Reforms, CTR. FOR AM. Progress (June 21, 2013). 


\section{JUDICIAL AUTHORITY, IMPARTIALITY, AND DECORUM, ON THE EVE OF THE “TAFT COURT"}

Early in the nation's history, Congress enacted a statute which prohibited federal judges from serving on cases in which the judge had a financial interest in the outcome. ${ }^{38}$ Toward the end of the Gilded Age, Congress began a process of implementing limited measures to govern the federal judiciary's qualifications to serve on particular trials. ${ }^{39}$ For instance, in 1891, Congress prohibited appellate judges from serving on appeals in which they had earlier served as a trial judge. ${ }^{40}$ In 1911 , Congress prohibited a judge from serving on a trial where the judge was also a witness. ${ }^{41}$ These laws were clearly limited to the narrow circumstances in which a federal judge was a property holder or shareholder, and the property or corporation was implicitly part of a trial in which the judge presided. Moreover, facially, the laws did not apply to the states, or, for that matter, the Supreme Court.

The Eighteenth Amendment establishing Prohibition, and the Volstead Act implementing the Amendment in federal law, are historically intertwined with the U.S. entry into World War I. ${ }^{42}$ Likewise, both the War and Prohibition tested the federal judiciary's authority as well as its impartiality. The timing of these events is important. On April 2, 1917, President Woodrow Wilson asked Congress to declare war on the Imperial German Government. ${ }^{43}$ Two days later, Senator Morris Sheppard, a Texas Democrat, introduced the Eighteenth Amendment's text for consideration to the Senate. ${ }^{44}$ Two days after the introduction of the Amendment, Congress, in following Wilson's request, declared war on the Imperial German Government. ${ }^{45}$ Six weeks later, Congress authorized a national conscription program under the Selective Draft Act and enacted a law titled as the Espionage Act. ${ }^{46}$ The Espionage Act prohibited

38 Act of May 8, 1792, ch. 36, § 11, 1 Stat. 178-79. In 1821, Congress expanded this prohibition to include a judge's near relatives, that is, the judge's siblings, parents, or children, from having a financial interest in the outcome. See Act of Mar. 3, 1821, ch. 51, 3 Stat. 643.

39 Charles Gardner, Judicial Disqualification: An Analysis of Federal Law, FeD. Jud. CTR., 2010 , at 5 .

40 Evarts Act, ch. 23, § 3, 26 Stat. 826 (1891).

41 Act of Mar. 3, 1911, ch. 231, § 20, 36 Stat. 1090.

42 See, e.g., G. Edward White, Law in American History: From Reconstruction Through the 1920s, at 296-97 (2016); Post, supra note 8, at 12; Justin CROWE, Bullding THE Federal judiciary: Law Courts and the Politics of Institutional Development 201 (2012).

43 Jennifer K. Elsea \& Matthew C. Weed, Declarations of War and Authorizations for the Use of Military Force: Historical Background and Legal Implications, Cong. RES. SERV., Apr. 18,2014 , at 76 .

44 Richard F. Hamm, Shaping the Eighteenth Amendment: Temperance Reform, Legal Culture, AND the Polity, 1880-1920, at 240 (1995).

45 James D. Richardson, A Compilation of the Messages and Papers of the Presidents, Vol. XVIII, at 8062-65 (1908); Act of Apr. 6, 1917, ch.1, 40 Stat.1. (declaring war on Germany); Richardson, Messages and Papers of the Presidents, supra. On December 7, 1917 Congress declared war on Germany's ally, the Austro-Hungarian Empire. See Act of Dec. 7, 1917, ch. 1, 40 Stat. 429 (declaring war on Austria-Hungary).

46 Act of Jun. 15, 1917, ch. 30, 40 Stat. 217. 
persons from interfering with the raising, training, and deployment of the nation's armed forces. ${ }^{47}$ At the same time, Congress authorized the Secretary of War to issue prohibitions to civilians on the sale of alcohol or prostitution near military bases, and violations of these regulations were punishable as crimes in federal court. ${ }^{48}$ Because of the Secretary of War's statutory authority to delegate rule making to military officers, the authorization was a remarkable grant of power from Congress to permit the Army to establish civil, rather than military, crimes and punishments without further legislation. ${ }^{49}$ In early 1918, Congress expanded the Espionage Act with the passage of the Sedition Act. ${ }^{50}$ Congress also investigated ties between American breweries and distilleries and Germany. ${ }^{51}$ By 1919 , over 500 people were convicted in the federal courts for violating the Espionage Act. ${ }^{52}$ Whether the majority of congressmen or federal judges realized it at the time, during the crisis of war and its aftermath during the so-called "Red Scare," the ability to preserve impartiality in the nation's courts would prove difficult. ${ }^{53}$ However, one prosecution in particular was to have a bearing on Taft's efforts to reshape the nation's judiciary.

47 See, e.g., United States v. Pierce, 245 F. 878, 880 (N.D.N.Y. 1917). Section 3 of the Espionage Act read:

Whoever, when the United States is at war, shall willfully make or convey false reports or false statements with intent to interfere with the operation or success of the military or naval forces of the United States or to promote the success of its enemies and whoever, when the United States is at war, shall willfully cause or attempt to cause insubordination, disloyalty, mutiny, or refusal of duty, in the military or naval forces of the United States, or shall willfully obstruct the recruiting or enlistment service of the United States, to the injury of the service or of the United States, shall be punished by a fine of not more than $\$ 10,000$ or imprisonment for not more than twenty years, or both.

48 See Act of May 18, 1917, ch. 15, § 13, 40 Stat. 76. This law was upheld in McKinley v. United States, 249 U.S. 397, 399 (1919).

49 See, e.g., Erwin Griswold, Government in Ignorance of the Law: A Plea for Better Publication of Executive Legislation, 48 HARV. L. REV. 198, 202 (1934). Griswold later served as Dean of Harvard University's law school and then Solicitor General of the United States during the administrations of Lyndon Johnson and Richard Nixon. See Lisa PruitT, ERwin Griswold, Great American Lawyers: An EnCyClopedia 302-03 (John R. Vile ed. 2001).

50 Act of May 16, 1918, ch. 75, § 1, 40 Stat. 553 (1918).

51 Brewing and Liquor Interests and German Propaganda and Bolshevik Propaganda, Hearing Before Sen. Comm. on the Judiciary, 65th Cong. (1919). Known as the "Overman Committee," after its chairman Senator Lee Slater Overman, a North Carolina Democrat, the investigation expanded into investigating the existence and impact of "Bolshevik" organizations in the United States. See John Thompson, Russia, Bolshevism, and the Versailles Peace 239 (1967).

52 Ronald K.L. Collins \& Sam Chaltain, We Must not be Afraid to be Free: Stories of FreE EXPRESSION IN AMERICA 24, (2011).

53 See, e.g., David Ray Papke, Heretics in the Temple: Americans Who Reject the NAtions Legal Faith 22 (Richard Delgado \& Jean Stefancic eds., 1998). One example of a federal judge involved in an extrajudicial governmental activity is Judge Julian Mack. In 1917, Judge Mack was appointed to a three-member board that oversaw conscientious objector claims. However, he also sat on several trials of citizens who refused to be inducted into the Army or Navy. See, e.g., Joshua E. Kastenberg \& Eric Merriam, In a Time of Total War: The 


\section{A. Berger v. United States}

Victor Luitpold Berger, a former Congressman of Austrian birth, was among the many citizens prosecuted under Espionage Act. ${ }^{54} \mathrm{He}$ was also a member of the Socialist Party of America and the owner and editor of the Milwaukee Leader, a socialist oriented newspaper. ${ }^{55}$ At the time of Berger's indictment and trial, he was in the process of running for an open senate seat in Wisconsin. ${ }^{56}$ In 1918, he and four codefendants delivered an affidavit to the U.S. District Court for the Northern District of Illinois to have federal judge Kenesaw Mountain Landis recuse himself. ${ }^{57}$ Berger and his codefendants alleged that Landis was biased against them on the basis that they were of German and Austrian birth and that Landis had, in other trials of persons charged under the Espionage Act or with evading conscription, openly denigrated Germans and pacifists. ${ }^{58}$ Landis' son was also a pilot in the nascent Army Air Service and actively engaged in the war against Germany. ${ }^{59}$ The governing judicial code, as enacted by Congress in 1912, required Landis to recuse himself from the trial on receipt of Berger's affidavit. ${ }^{60}$ Landis refused to do so, and Berger and his

Federal Judiciary AND the National Defense, 1940-1954, at 12 (2016); SECOND RePort OF the Provost Marshal to the Secretary of War on the Operation of the Selective SERVICE System To DeCEMBER 20, 1918, at 60 (1919). Interestingly, in 1917, Judge Mack kept Taft informed of his role in advising Congress on drafting a federal insurance program for soldiers and Taft supported Mack's role in advising Congress on this program. See Letter from Julian Mack, Judge, U.S. Court of Appeals for the Seventh Circuit, to William Howard Taft, Chief Justice, U.S. Supreme Court (Aug. 25, 1917); and Letter from Taft, to Mack (Aug. 22, 1917) (on file in the Library of Congress).

54 William H. Thomas, UnSAFe FOR Democracy: World War I AND the U.S. JUSTiCe Department's Covert CAMPAign to SupPress Dissent 113 (Paul S. Boyer ed., 2008).

55 For more information on Berger, see id.

56 Berger v. United States, 255 U.S. 22 (1921).

57 Id. at 27.

$58 I d$.

59 David Pietrusza, Judge and the Jury: The Life and Times of Judge Kenesaw MounTAin LANDis 110 (1988). Like Judge Landis, the recently deceased Justice Antonin Scalia's son was in the Army and served in Afghanistan. In a speech at the University of Freiburg in Switzerland, presaging his dissent against the Court's ruling in Boumediene v. Bush, 553 U.S. 723 (2008), he stated in response to a question:

Give me a break ... Hamdan . . . is arguing that the federal courts should have jurisdiction over his case, . . . if he was captured by my army on a battlefield, that is where he belongs. I had a son on that battlefield, and they were shooting at my son, and I'm not about to give this man who was captured in a war a full jury trial. I mean, it's crazy.

Judge 'Rejects Guantanamo Rights': A US Supreme Court Justice Has Been Quoted as Saying That Guantanamo Detainees Do Not Have the Right to be Tried in Civil Courts, BBC News (Mar. 27, 2006); see also Johnathan Turley, Our Loquacious Justices, Los ANGeles Times, Mar. 28, 2006. For reasons that should be apparent in the text, neither Taft nor Holmes would have likely approved of Scalia's speech.

60 See, e.g., Henry v. Speer, 201 F. 869 (5th Cir. 1913); see also Act of Mar. 3, 1911, ch. 231, 36 Stat. 1087. 
codefendants were found guilty and sentenced to long terms in prison. ${ }^{61}$ In Berger $v$. United States, a decision authored by Justice Joseph McKenna, the Court determined that Landis' failure to recuse himself in compliance with the governing statute required overturning the appellants' convictions. ${ }^{62}$ Justices William Rufus Day, James Clark McReynolds, and Mahlon Pitney dissented. ${ }^{63}$

The majority opinion is antiseptic in that it merely addresses the requirements of the judicial code, rather than the full range of Landis' conduct or a constitutional right to an impartial judge. Indeed, Justice Holmes noted to his frequent correspondent Harold Laski that "the opinion was not all [he] could wish for," and Holmes then went on to note that Day's dissent was "feeble" and McReynolds' dissent "improper in its rhetoric." ${ }^{64}$ Holmes concluded his letter by observing, "Landis always seems to make himself conspicuous in ways that I lament." ${ }^{65}$ Holmes' observation on Landis is noteworthy for another reason. Berger's trial and Landis' wartime judicial conduct were widely reported in the nation's newspapers. ${ }^{66}$ The New York Tribune reported that Landis had responded to Berger's affidavit by calling it "a slander." 67 In 1920, Landis proclaimed to a meeting of business executives in Chicago, "It was my great disappointment to give Berger only 20 years in Leavenworth. I believe the law should have enabled me to have him lined up against the wall and shot." 68

Landis became a well-known figure in 1919 after his appointment as Commissioner of Major League Baseball. ${ }^{69}$ Several scholars have characterized Landis' dual service as baseball commissioner and federal judge as a conflict of interest which became the impetus for the American Bar Association's 1924 Judicial Code. ${ }^{70}$ Taft was instrumental in creating this "first ever" judicial code, and he had

61 Berger, 255 U.S. at $27,36$.

62 Id.

63 Id.

64 Letter from Oliver Wendell Holmes, Associate Justice, U.S. Supreme Court, to Harold J. Laski, Political Theorist (January 3, 1921) (on file in the Library of Congress).

65 Id.

66 As a sampling of other newspapers see Berger Conviction Reversed By Court, N.Y. Times, Feb. 1, 1921, at 1; Judge Landis Overrules Dismissal Plea-Defendant's Kin a Deserter, N.Y. Sun, Dec. 19, 1918; Judge Landis Puts a Stop to Delays of Socialist Defendants, WASHINGTON HERALD, Dec. 11, 1918, at 1.

67 Socialists' Trial Set: Judge Landis Denies Berger a Change of Venue, N.Y. TRIBUNE, Nov. 17, 1918.

68 Pietrusza, supra note 59, at 149; Landis Regrets He Could Not Sentence Berger to be Shot, N.Y. Times, Dec. 30, 1919 at 1.

69 See, e.g., Nathaniel Grow, Baseball on Trial: The Origin of Baseball's AntitRust EXEMPTION 68 (2014); Shayna M. Sigman, The Jurisprudence of Judge Kenesaw Mountain Landis, 15 MARQ. SpORTS L. Rev. 277, 277-78 (2007). In the 1988 movie Eight Men Out, actor John Anderson played the role of Landis.

70 See, e.g., Geoffrey C Hazzard et AL., LaW of LaWyering 695 (Vol. 2, 2015); Ronald R. Rotunda, Professional Responsibility, 327 (2008); Molly McDonough, Bench Battles Become Vocal: ABA Reviews Judges' Code as Judicial Speech, Once Muzzled, Finds its Voice Again, 19 A.B.A.J., 18-20 (2003); Frank L. DeWey, ThOmas JefFerson LaWyer 81 (1986); 
little regard for Landis. ${ }^{71}$ But Taft's dislike of Landis was much deeper than Landis' conflict of interest as baseball commissioner, and the model judicial code came about for several reasons. In 1910, while serving as President, Taft told the Detroit Times that Landis was "an obscure demagogue of a judge." 72 What Taft did not say to the Detroit newspaper was also important. Landis had a personal relationship with Taft through Taft's older brother, Charles Phelps Taft, who simultaneously owned two major league baseball teams, the Philadelphia Phillies and Chicago Cubs, and Landis opposed a person owning two teams. ${ }^{73}$ Moreover, in 1912, Taft, while in his last year as President, removed Landis' older brother from a postmaster position after accusing him of neglect of duties. ${ }^{74}$ In 1921, the House of Representatives Judiciary Committee investigated Landis' conduct with the possibility of drafting articles of impeachment against him. ${ }^{75}$ Congressman Benjamin Welty, an Ohio Democrat, accused Landis of violating ethics norms for serving as commissioner of baseball and his federal judgeship at the same time. ${ }^{76}$ However, Landis departed the bench by the time the House could complete its report. ${ }^{77}$

\section{B. Judicial Biography}

It has been observed that Taft had an affinity for the Judicial Branch over the Executive Branch and an overarching desire to become Chief Justice. ${ }^{78} \mathrm{He}$ also had an interest in reforming the judiciary by stemming progressive influences on it because he believed that "progressive" changes to the law should only originate in the elected branches of government. ${ }^{79}$ His distrust of progressive judges stemmed from the belief

Robert B. McKay, The Judiciary and Nonjudicial Activities, 35 LAW \& CONTEMP. Probs. 9, 14 (1970); AM. BAR Ass'N, LANDis Resolution, 46 ReP. OF THE A.B.A. 61-67 (1921).

71 Chief Justice Roberts, 2011 Year-end Report on the Federal Judiciary, 1-2 (Dec. 31, 2011). See, e.g., Conduct of Judge Kenesaw Mountain Landis, Hearings Before H. Comm. on the Judiciary, 65th Cong. 4-6 (1921).

72 PIETRUSZA, supra note 59, at 97.

73 Id. at 73.

74 Taft Removes Landis, San Juan Postmaster Who Aided Roosevelt Accused of Neglect, N.Y. Times, Aug. 13, 1912, at 6.

75 Conduct of Judge Kenesaw Mountain Landis, supra note 71.

76 Id. at 5.

77 Landis Quits to Aid Legion and Baseball: Too Much Work His Excuse to Public, Chicago Sunday Tribune, Feb. 19, 1922, at 1.

78 Peter G. Renstrom, The Taft Court: Justices, Rulings, and Legacy 72-73 (2003); John Anthony Maltese, The Selling of Supreme Court Nominees 47-48 (1998).

79 Renstrom, supra note 78, at 72-73; see also Donald F. Anderson, Building National Consensus: The Career of William Howard Taft, 68 U. CIN. L. REV. 323, 340-41 (2000); William Howard Taft, The Attacks on the Court and Legal Procedure, 5 KY. L.J. 1, 8 (1916). Taft noted:

The third criticism of this class against judges and courts is that in the application of the common law to new conditions, judges are out of touch with social progress and reform. They are, it is said, rigid and reactionary and fail to shape their so-called judge-made law to hasten the steps of society to the better things that social reformers plan. Indeed, this is said to be true of our courts not only in the application of the common law, but also in their construction of constitutions and the interpretation of statutes. The proper 
that such judges created law. ${ }^{80}$ Taft was born in 1857 in Cincinnati to a political family whose roots stretched to the nation's founding. ${ }^{81}$ His father, Alfonso Taft, had served as both Secretary of War and Attorney General during Ulysses Grant's presidency and later as both U.S. Minister to Austria-Hungary and Russia during Chester Arthur's presidency. ${ }^{82}$ Taft was educated at Yale University as well as the Cincinnati Law School, the predecessor of the University of Cincinnati's law school. ${ }^{83} \mathrm{He}$ then, in order, served as: assistant prosecutor of Hamilton County, Ohio, Ohio's internal revenue collector, Hamilton County solicitor, superior court judge of Hamilton County, Solicitor General of the United States, law school professor and dean of the Cincinnati Law School, judge on the United States Court of Appeals for the Sixth Circuit, Governor of the Philippine Islands, and Secretary of War. ${ }^{84}$ He was elected President of the United States in 1908, but in 1912, he lost to Woodrow Wilson in a four-way race against Wilson, Theodore Roosevelt, and Eugene Debs. ${ }^{85}$ In contrast to Debs, who ran as a socialist; Roosevelt, who ran as a liberal progressive; and Wilson, who also ran as a progressive reformer, Taft was the most conservative of the candidates even though he too embraced aspects of progressivism. ${ }^{86}$ From 1913 until 1921, when President Warren G. Harding nominated Taft as Chief Justice, Taft taught at Yale, remained active in the law, and generally supported Wilson's efforts to have the country join the League of Nations. ${ }^{87}$

Among the myriad features involving Taft's efforts at judicial reform, three aspects of his judicial conduct must be taken into consideration when assessing Tumey. The first is that by the time of Tumey's appeal, Taft had been accused of being beholden

discharge of the difficult duties of courts requires as judges men of great ability, wide experience, profound learning, independence and force of character, of nice discriminating judicial quality, and with the statesmanlike perception of the distinction between those fundamental principles of law that must be constantly maintained and preserved in any useful system of government and of the casual and temporary rules of human conduct that may be changed from time to time as conditions change, in the promotion of social justice and the pursuit of community happiness.

Id. at 8 .

80 See, e.g., Edward A. Purcell, Brandeis and the Progressive Constitution: Erie, the Judicial Power, and the Politics of the Federal Courts in Twentieth-Century America 21-22 (2000); Edgar J. McManus \& Tara Helfman, Liberty and Union: A Constitutional History of the United States 254 (concise ed. 2014); David Henry Burton, TAFt, Holmes, AND the 1920s Court: An ApPraisal 42 (1988); Stanley I. Kutler, Chief Justice Taft and the Delusion of Judicial Exactness: A Study in Jurisprudence, 48 VA. L. REV. 1407 (1962).

81 Timothy L. Hall, Supreme Court Justices: A Biographical Directory 275-78 (2001).

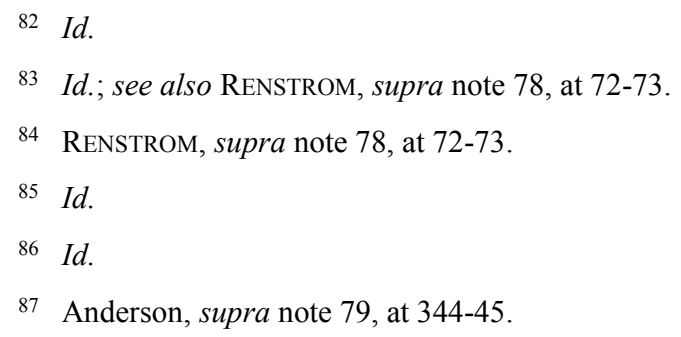


to corporate interests. ${ }^{88}$ In 1923 , the Court invalidated a federal minimum wage as it applied to women in the District of Columbia in Adkins v. Childrens' Hospital. ${ }^{89}$ Adkins narrowed the reach of prior decisions that upheld state legislative restrictions on wages and working conditions. For instance, in 1908, the Court upheld state laws on the number of hours that women could be employed in certain occupations as a matter of the state exercising its police power to ensure the health of women. ${ }^{90}$ Nine years later, the Court upheld Oregon's law capping a workday for both women and men at ten hours. ${ }^{91}$ Taft dissented in Adkins and noted that although reducing the number of hours an employee worked might not be wise in solving the "evils of the sweating system," a state legislature, or, in this instance, Congress, should at least possess the lawful authority to do so. ${ }^{92}$

Following the Court's issuance of Adkins, newspaper magnate William Randolph Hearst attacked Taft as being "a sop" to "bankers and corporations," even though Taft had dissented from the majority. ${ }^{93}$ Hearst may have believed that Taft's dissenting opinion was tepid in its criticism of the majority's opinion. The attack was based on Taft's relationship to Andrew Carnegie, one of the world's wealthiest citizens who had amassed a fortune in iron and steel production. ${ }^{94}$ In 1919, Carnegie designated millions of dollars to an endowment for the purpose of promoting world peace, and an independent agency, which Taft officered, paid Taft's salary through the endowment. ${ }^{95}$ However, Taft did not learn of the endowment until 1919, and because the annuity that was granted as part of the endowment was not tied to United States Steel - the successor of Carnegie's various corporations - he did not believe that there was any conflict of interest. ${ }^{96}$ Taft also decided, following Hearst's attack on him, that the annuity had to be transferred to Yale University but that he could not resign from

88 See RENSTROM, supra note 78, at 190-92.

89 Adkins v. Children's Hosp. of D.C., 261 U.S. 525, 562 (1923).

90 Muller v. Oregon, 208 U.S. 412, 416-17 (1908).

91 Bunting v. Oregon, 234 U.S. 426, 434, 438 (1917).

92 Adkins, 261 U.S. at 562 (Taft, C.J., dissenting). Taft's language in his dissent is helpful for placing criticisms against him in context. He wrote:

Now, I agree that it is a disputable question in the field of political economy how far a statutory requirement of maximum hours or minimum wages may be a useful remedy for these evils, and whether it may not make the case of the oppressed employee worse than it was before. But it is not the function of this Court to hold congressional acts invalid simply because they are passed to carry out economic views which the Court believes to be unwise or unsound.

Id. However, he went on to note that he did not concur with Holmes' more forceful dissent in which Holmes scoffed at the majority's use of "liberty of contract." Id. at 563.

93 William G. Ross, A Muted Fury: Populists, Progressives, and Labor Unions CONFront THE COURTS, 1890-1937, at 234 (1994).

94 Id.

95 Id. (citing Letter from William H. Taft, Chief Justice, U.S. Supreme Court, to Thomas W. Shelton, Executive Boardmember, California State Bar Ass'n (June 23, 1923)).

96 Ross, supra note 93 , at 234-35. 
the Court because to do so would be a tacit admission of wrongdoing when no wrongdoing had occurred. ${ }^{97}$ Taft wrote to his oldest son Robert that:

Hearst, who is attacking the Court generally, and is now attacking it because I accepted the bequest of an annuity from Carnegie in his will. It has given me a great deal of concern. I accepted it before I was on the bench, and I am quite sure I would not have accepted it had I been on the bench. I would be quite willing now to give it up or to assign it for some good purpose, but I don't like to do it under fire, so that I suppose I shall have to stand the battering, which is quite nerve straining when one in engaged in work that should command all his attention. ${ }^{98}$

Taft was not only offended with Hearst's accusation; he also blamed Senators Robert La Follette and George Norris for the negative publicity and calls for Taft's resignation..$^{99}$ There is an irony to Hearst's attack on Taft. In 1916, Taft wrote an article in the University of Kentucky Law Review about the state of the judiciary across the nation. ${ }^{100}$ In regard to the lesser state courts, he penned, "If a system could be devised that offered greater advantage to the wealthy litigant in resisting the claims of the poor litigant, I don't know what it is." 101

A second aspect of Taft's judicial tenure is that he remained politically active in consulting with his Republican peers on the best means to preserve the presidency in conservative Republican hands. ${ }^{102}$ For instance, in April 1928, he informed his son Robert that he had advised the Republican Party's directors of the best means to have Herbert Hoover nominated. ${ }^{103}$ In 1923, President Coolidge had Taft work on part of his State of the Union Address. ${ }^{104}$ None of Taft's political actions are surprising in light of the fact that he was a former President, and when also considering his efforts to achieve internal judicial reform with minimal congressional oversight, he may have found nothing unethical or untoward in coupling his lobbying on judicial administration efforts with political advice. As noted below, by the time of Tumey, Taft had also regularly corresponded with senior officers of the nation's most politically powerful pro-Prohibition organization, the Anti-Saloon League. ${ }^{105} \mathrm{By}$

97 Id. at 235.

98 Letter from William H. Taft, Chief Justice, U.S. Supreme Court, to Robert Taft, son of William H. Taft (Apr. 16, 1923).

99 Letter from William H. Taft, Chief Justice, U.S. Supreme Court, to Frank H. Hiscock, Chief Judge, New York Court of Appeals (Apr. 12, 1922).

100 See Taft, supra note 79.

101 Id. at 21.

102 See, e.g., William H. Taft, Chief Justice, U.S. Supreme Court, to Robert Taft, son of William H. Taft (Apr. 27, 1924). In this letter, Taft informs his son Robert that at a gathering of Republicans he explained, "The only hope of the Republican Party is Coolidge and I thought Coolidge's best course was to veto every bill that he seriously questioned." Id.

103 Letter from William H. Taft, Chief Justice, U.S. Supreme Court, to Robert Taft, son of William H. Taft (Apr. 15, 1928).

104 See, e.g., CROWE, supra note 42, at 206.

105 See infra notes 391, 393, 396, and accompanying text. 
1908, the Anti-Saloon League had established offices in forty-three states, and the organization had allied not only with Protestant revival movements, but also with women's suffrage organizations. ${ }^{106}$

Finally, Taft's view of Prohibition and the public's perception of his support, or lack of support, for enforcement of the Volstead Act must be considered. Taft became Chief Justice shortly after the Eighteenth Amendment and the Volstead Act became fixtures in American society, and he had never publicly supported the passage of either measure. ${ }^{107}$ As President, he vetoed the Webb-Kenyon Act, a law requiring the federal government to prevent the shipment of alcohol from a state without prohibition laws to a state that prohibited alcohol. ${ }^{108}$ Taft's reasoning behind his veto was that the act was constitutionally dubious in that it placed too much authority over individual states to influence the federal government, but Congress overrode his veto. ${ }^{109}$ In 1917, the Court upheld the act's constitutionality, and prohibitionists lampooned Taft as a drunk for his earlier veto, leaving the impression that he did not support efforts to outlaw liquor. ${ }^{110}$ In light of this "public impression," Taft's actions in Tumey are noteworthy given that the decision was clearly not pro-liquor enforcement.

In a short time, doubts as to whether Taft supported the Eighteenth Amendment and the Volstead Act were overshadowed by the certainty of his passion for ensuring that the criminal laws were enforced. For instance, in Carroll v. United States, Taft led a majority of the Court to uphold the warrantless search of vehicles suspected of transporting alcohol in violation of the Volstead Act. ${ }^{111}$ Prior to the issuance of Carroll on March 2, 1925, Taft had written to Horace, "The automobile is the greatest instrument for promoting immunity of crimes of violence." ${ }^{12}$ The automobile had, in fact, been instrumental to "bootleggers," and although Justice McReynolds recognized this fact in the first sentence of his dissent, he took Taft and the majority to task for carving out a Fourth Amendment exception for the singular purpose of enforcing the Volstead Act. ${ }^{113}$ Likewise, in Olmstead v. United States ${ }^{114}$ Taft led the Court to uphold

106 See J.C. Jackson, The Work of the Anti-Saloon League, 32 AnNuALS OF THE AM. ACAD. OF Pol. AND Soc. SCI. 12 (1908).

107 Michael J. Gerhardt, The Forgotten Presidents: Their Untold Constitutional Legacy 189 (2013); David E. Kyvig \& Honoree Fannone JefFers, Repealing National PROHIBITION 32 (2000).

108 Daniel Okrent, Last Call: The Rise and Fall of Prohibition 58 (2010); John Milton Cooper, Pivotal Decades: The United States, 1900-1920, at 128 (1990).

109 COOPER, supra note 108.

110 Clark Distilling Co. v. Western Md. Ry. Co., 242 U.S. 311, 320 (1917).

111 Carroll v. United States, 267 U.S. 132, 162 (1925).

112 Letter from William H. Taft, Chief Justice, U.S. Supreme Court, to Horace D. Taft, brother of William H. Taft (Nov. 16, 1923).

113 Carroll, 267 U.S. at 163 (McReynolds, J., dissenting). Justice McReynolds, with Justice Sutherland joining, penned as the first sentence, "The damnable character of the 'bootlegger's' business should not close our eyes to the mischief which will surely follow any attempt to destroy it by unwarranted methods." Id.

114 Olmstead v. United States, 277 U.S. 438 (1928). 
a conviction under the Volstead Act obtained through warrantless wiretap evidence. ${ }^{115}$ Moreover, shortly after the Court issued Tumey, he complained to his son Charles Phelps Taft II, a county prosecutor, that Congress had failed to adequately fund the Treasury Department to hire enough prohibition agents. ${ }^{116}$ One month after his complaint against Congress, Taft encouraged Charles to prosecute bootleggers to his fullest ability in writing:

I am sorry to hear of your crime wave in Cincinnati. The immunity of these bootleggers, due to the original conspiracy that prevents and terrorizes the natural witnesses of the crime, is something I presume they have had in other parts of the country. There is nothing to do but just keep at it and hire more detectives, if you need them, and after a while you will begin to get the thread and then you will have a collection of crimes and convictions that will break the thing up, but it needs hard work and close investigation. ${ }^{117}$

In 1925, he tried to place into an annual Judicial Conference report that one of the reasons for the federal district court caseload congestion was because several states had yet to enact or adequately enforce "little Volstead statutes."118 Ironically, Ohio's liquor prosecution laws were partly designed to ease congestion in the state and federal courts. Finally, shortly after the Court issued Tumey, Taft wrote to the editor of the Cincinnati Times-Star:

We could not avoid declaring the law in respect to such trials to be contrary to due process. It is one of those instances in which an enthusiastic Attorney General anxious to secure the proper enforcement of the prohibition law forgot the rights of individual defendants as secured by the Constitution. ${ }^{119}$

Taft, of course, was merely the "first among equals," and the other eight justices had differing jurisprudential philosophies. In 1927, the Court consisted of Justices Oliver Wendell Holmes, Jr., Willis Van Devanter, James Clarke McReynolds, Louis Brandeis, George Sutherland, Pierce Butler, Edward T. Sanford, and Harlan Fisk Stone. ${ }^{120}$ With the exception of Holmes and Brandeis, and to a lesser degree Stone, the

115 Id. at 468-69.

116 Letter from William H. Taft, Chief Justice, U.S. Supreme Court, to Charles P. Taft, brother of William H. Taft (July 9, 1927).

117 Letter from William H. Taft, Chief Justice, U.S. Supreme Court, to Charles P. Taft, brother of William H. Taft (Aug. 7, 1927).

118 Peter Graham Fish, The Politics of Federal Judicial Administration 48 (1973). That Ohio had passed such a "little Volstead" statute provides some irony to Tumey because the state had, in a sense, assisted in Taft's goal of a responsive judiciary.

119 Letter from William H. Taft, Chief Justice, U.S. Supreme Court, to Moses Strauss, Editor, Cincinnati Times-Star (Mar. 8, 1927). Charles Phelps Taft, Sr., an older brother of the Chief Justice's, owned the Cincinnati Times-Star. See Clarence E. Wundelin, Jr, The PaPers OF ROBERT TAFT, VOL I, 1889-1926, at 288 (1997).

120 Bernard Schwartz, A History of the Supreme Court 384 (1993). 
Court was decidedly conservative and wary of the judicial extension of federal power over state authority. ${ }^{121}$

Theodore Roosevelt nominated Holmes to the Court in 1902. ${ }^{122}$ Holmes had, by the time of his appointment, become one of the leading legal scholars in the Englishspeaking world. ${ }^{123}$ Born in Boston in 1841 to a father who was a nationally known poet, Holmes served in Union Army in the Civil War, graduated from Harvard University's law school in 1867, authored legal treatises, and was appointed to the Massachusetts Supreme Judicial Court in 1882. ${ }^{124}$ By the time of Tumey, Holmes was considered a progressive justice and had dissented in several notable cases in which he believed the federal and state governments had unconstitutionally trammeled the free speech rights of citizens during and immediately after World War I. ${ }^{125}$

Willis Van Devanter was born in 1859 in Indiana and, like Taft, attended the predecessor to the University of Cincinnati's law school. ${ }^{126}$ At the age of thirty, he moved to the Wyoming Territory and became involved in Republican state politics. ${ }^{127}$ In a short time, Senator Francis E. Warren became his benefactor. ${ }^{128}$ Warren was one of the "old guard" conservatives in Congress, and he successfully lobbied Roosevelt to appoint Van Devanter to the United States Court of Appeals for the Eight Circuit. ${ }^{129}$ In 1910, under pressure from Warren, Taft nominated Van Devanter to the Court,

121 Id. at 383-85.

122 Id. at 384 .

123 Archibald Cox, The Court and the Constitution 151-53 (1987).

124 See, e.g., G. Edward White, Justice Oliver Wendell Holmes: LaW AND the INNER Self 297 (1993); John Kang, The Soldier and the Imbecile: How Holmes's Manliness Fated Carrie Buck, 47 AKRON L. Rev 1055, 1067-69 (2015) (describing how Holmes's military experiences in the Civil War contributed to his decision in Buck v. Bell).

125 Holmes authored Schenck $v$. United States, upholding a conviction for the exercise of speech, which was deemed to interfere or obstruct conscription under the 1917 Selective Service Act. Schenck v. United States, 249 U.S. 47 (1919). This decision was issued on March 3, 1919. He also authored Frohwerk v. United States, in which a conviction for the publications of articles deemed to undermine the draft was upheld. Frohwerk v. United States, 249 U.S. 204 (1919). This decision was issued on March 10, 1919. Likewise, Holmes authored Debs v. United States, in which a conviction against labor leader Eugene Debs was upheld on the basis of Debs allegedly inciting mutiny and public refusal to comply with the Selective Service Act. Debs v. United States, 249 U.S. 211 (1919). This decision was issued on the same day as Frohwerk. All three of these decisions were unanimously decided. By the end of 1919, Holmes began to dissent in similar cases, including Abrams v. United States, 250 U.S. 616 (1920), Schaefer v. United States, 251 U.S. 466 (1920), and Pierce v. United States, 252 U.S. 239 (1920). According to some scholars, these dissents cemented Holmes' reputation as a progressive justice who championed free speech rights. See, e.g., Thomas Healy, The Great Dissent: How Oliver Wendell Holmes Changed His Mind - And Changed the History of Free Speech in America 5 (2013); Kermit Hall \& John J. Patrick, The Pursuit of Justice: Supreme Court DECISIONS THAT SHAPED AMERICA 77-81 (2006).

126 Walter F. Pratt, JR., The Supreme Court Under Edward Douglass White: 19101921, at 21-23 (1999).

127 Id. at 22.

128 Id.; see also RENSTROM, supra note 78, at 27-28.

129 Pratt, supra note 126. 
where he became one of the more conservative justices. ${ }^{130}$ Van Devanter was noted for his inability to write opinions in a timely manner. ${ }^{131}$

Two of Woodrow Wilson's judicial appointees remained on the Court at the time of Tumey: James Clarke McReynolds and Louis Dembitz Brandeis. The two justices were opposites in almost every conceivable manner. ${ }^{132}$ McReynolds was born in 1862 in Kentucky and attended Vanderbilt University, where he graduated as valedictorian in $1882 .{ }^{133} \mathrm{He}$ later attended the University of Virginia and then served as a secretary to Howell Edmunds Jackson, a United States senator and later Supreme Court justice. ${ }^{134}$ Wilson nominated McReynolds as Attorney General in 1913 and then to the Court in 1914. ${ }^{135}$ Although McReynolds vigorously prosecuted antitrust violations, he was not a progressive and became one of the more conservative justices, as well as the Court's leading bigot in the twentieth century. ${ }^{136}$

In contrast, Brandeis had been a long-time progressive, and after graduating from Harvard University's law school, he fought to uphold limitations on working hours, a minimum wage, and workplace safety regulations. ${ }^{137} \mathrm{He}$ also distrusted the power of large corporations over elected governments. ${ }^{138}$ Brandeis was born in 1856 in Kentucky to immigrant Jewish parents from the Habsburg Empire and graduated from high school at the age of fourteen and law school at the age of eighteen. ${ }^{139}$ His nomination to the Court in 1916 was one of the more contentious in American history, and much opposition to him stemmed from his Jewish faith. ${ }^{140}$ Indeed, Taft vigorously lobbied Republicans to oppose Brandeis. ${ }^{141}$ Like Holmes, Brandeis dissented from

130 Pratt, supra note 126; see also Melvin Urofsky, The Supreme Court Justices: A BIOGRAPHICAL DictionARY 485-86 (1994).

131 Edward White, The American Judicial Tradition: Profiles of Leading American JUDGES 184-85 (1988); SCHWARTZ, supra note 120, at 206.

132 See, e.g., James MacGregor Burns, Packing the Court: The Rise of Judicial Power AND the COMING OF THE Supreme Court 126-27 (2009). Burns writes, "Wilson's second nominee for the Supreme Court could scarcely have been more different than McReynolds, or better chosen to redeem the president's promise to purify the judiciary. Louis D. Brandeis was also a Southerner, born and raised in Louisville, but there the resemblance with McReynolds ended." Id.

133 Hall, supra note 81, at 263; James E. Bond, I Dissent: The Legacy of Justice James Clark McReynolds 1-2 (1992).

134 Bond, supra note 133, at 21.

135 Id. at 36-50.

136 Id. at 52; see also Henry Julian Abraham, Justices, Presidents, and Senators: A History of the U.S. SuPREME COURT APPOINTMENTS FROM WASHington to CLINTON 133-35 (1999) U.S. Supreme Court ApPointMents from WASHington to Clinton, 133-135 (REV. ED. 1999)

137 PURCELL, supra note 80, at 116.

138 Id. at 111.

139 Rebecca Shoemaker, The White Court: Justice Rulings And Legacy 91 (2004).

$140 \quad I d$.

141 Id. at 93. 
decisions which encroached into free speech, and he continued to champion workplace safety and wages regulations. ${ }^{142}$

In addition to Taft as Chief Justice, President Warren G. Harding appointed George Sutherland, Pierce Butler, and Edwin Sanford to the Court. Sutherland was born in England in 1862 and immigrated to Utah with his parents one year later. ${ }^{143} \mathrm{He}$ was educated by his parents and worked in a clothing store and as an agent for Wells Fargo before entering the Brigham Young Academy to study law. ${ }^{144}$ In 1881, he began a formal course of legal study at the University of Michigan's law school, and after passing that state's bar examination one year later, he returned to Utah. ${ }^{145}$ In 1900, Utah's voters sent him to the House of Representatives as a Republican, where he served a single term. ${ }^{146}$ In 1904, the Utah state legislature sent him to the Senate, where he served for two terms. ${ }^{147}$ Sutherland supported women's suffrage, befriended Taft, and, after leaving the Senate, became the American Bar Association's president. ${ }^{148}$ Taft endorsed Sutherland's position on the Court to President Harding. ${ }^{149}$

Pierce Butler has not fared well in the legal academy. He has been called "the least gifted and in many ways the most doctrinaire of the [so-called] four horsemen." 150 Taft, however, lobbied Harding to nominate Butler to the Court. ${ }^{151}$ Senator George Norris, Taft's chief opponent in the Senate, vocally opposed Butler's nomination to the Court because of his ties to "corporate interests." ${ }^{152}$ Norris was not alone in his opposition. Liberals and progressives opposed Butler as well. ${ }^{153}$ Harding's last

142 Id. at 94.

143 Edward L. Carter \& James C. Phillips, The Mormon Education of a Gentile Justice: George Sutherland and Brigham Young Academy, 33 J. Sup. Ст. НisT. 332, 332 (2008).

144 Andrew Morse, The New Respect for Justice Sutherland, 25 UTAH BAR. J. 18, 19 (2012).

145 Id. at 18.

146 Hadley Arkes, The Return of George Sutherland: Restoring A Jurisprudence of NATURAL RightS 48 (1994).

147 Id. at 23.

148 Morse, supra note 144, at 20.

149 Douglas Clouatre, Presidents And Their Justices 224 (2010).

150 Henry Julian Abraham, Justices, Presidents, and Senators: A History of the Supreme Court ApPointments From Washington to Bush II 149 (5th ed. 2008). According to Abraham, Taft had lobbied Harding to appoint former Solicitor General John W. Davis, but Harding was unwilling to consider appointing a Democrat to the bench, even though Davis was a conservative from West Virginia. $I d$. Abraham also notes that Butler had a prejudice against Germans and socialists. Id. This would have placed Butler in the same category as Landis.

151 Id. There is an irony to Butler's reputation. In 1964, David Danelski published the only full-length study of Butler. See generally David Danelski, A Supreme Court Justice IS APPOINTED (1964). In a review of the book, noted legal historian Loren Beth conceded that book had "admirable objectivity," but was a "failure to make a serious attempt to place the appointment within its political, social, and historical framework . . . " Loren Beth, Book Review: A Supreme Court Justice is Appointed, 27 J. PoL. 675-77 (1965).

152 Letter from George Norris, U.S. Senator, Neb., to Henrik Shipstead, U.S. Senator, Minn. (December 7, 1922) (on file in the Library of Congress).

153 ABRAHAM, supra note 136 , at 143. 
appointment is, perhaps, more historically obscure than Butler. In 1923, Harding nominated Edward Terry Sanford to the Court, but he served for only seven years and is best remembered for authoring the majority opinion in Gitlow v. New York, ${ }^{154}$ a decision which upheld a New York conviction under New York's criminal syndicalism statute was based on speech, and Whitney v. California, ${ }^{155}$ which upheld California's anti-syndicalism that criminalized association with an organization whose alleged aim was to "overthrow" the government. 156

Harlan Fiske Stone was the most junior of the justices serving on the Court at the time of Tumey, having been appointed by President Coolidge in 1925. ${ }^{157}$ Stone had been Coolidge's college friend at Amherst University and served as Coolidge's Attorney General for a year prior to his judicial nomination. ${ }^{158} \mathrm{He}$ was born in 1875 , attended Columbia University's law school, and later became its dean. ${ }^{159} \mathrm{He}$ also worked in private practice and became a partner at Sullivan and Cromwell. ${ }^{160}$ Coolidge sought Stone's help in rooting out corruption in the Justice Department. ${ }^{161}$ Over time, Stone generally aligned with Brandeis and Holmes on appeals from criminal convictions as well as regarding the extent of federal authority over individual citizens..$^{162}$

\section{Taft and the Shaping of Judicial Governance}

Taft was directly responsible for two statutory changes in the federal judiciary. In 1922, Congress passed the Judicial Conference Act, which enabled a chief justice to assign district court judges outside of their districts on a temporary basis. ${ }^{163}$ This part of the law was related to Prohibition in the sense that the numbers of criminal trials dramatically increased in some federal judicial districts - particularly those near the Canadian border. ${ }^{164}$ The Anti-Saloon League's leaders viewed this change with suspicion and accused Taft of seeking to place "wet judges" in areas with a large prohibition caseload. ${ }^{165}$ The law also created the Judicial Conference, an annual meeting between the senior circuit judges and the Chief Justice to craft legislative

\footnotetext{
154 Gitlow v. New York, 268 U.S. 652, 654 (1925).

155 Whitney v. California, 274 U.S. 357 (1927).

156 Id. at $363,372$.

157 Melvin I. Urofsky, Division and Discord: The Supreme Court Under Stone and Vinson, 1941-1953, at 10 (1997); Alpheus Thomas MASON, HARLAN F. STONE: Pillar OF THE LAW 5 (1953).

158 RENSTROM, supra note 78 , at 80.

159 Id.

160 Id.

161 Melvin L. Urofsky, The Supreme Court Justices: A Biographical Dictionary 425 (1994).

162 Id. at 426.

163 CROWE, supra note 42, at 210.

164 FISH, supra note 118, at 46-47.

165 Id. at 103.
} 
proposals to Congress. ${ }^{166}$ In 1925, Taft convinced Congress to enable to the Court to gain a greater degree of control over its own docket. In what became known as the Judiciary Act of 1925, Congress reduced the obligatory jurisdiction of the Court and replaced it with "certiorari jurisdiction." 167 In both instances, Taft had to overcome opposition from not only Senators Norris and Robert LaFollette, but also Senator Thomas Walsh, a powerful member of the Judiciary Committee. ${ }^{168}$

The Judiciary Act bears further mention than one sentence. From his time as a judge on the Court of Appeals for the Sixth Circuit, Taft had concluded that appeals accepted by the nation's highest court should only be constitutional in nature. ${ }^{169}$ In 1910 , in his second annual address to Congress, Taft stated, "No man ought to have, as a matter of right, a review of his case by the Supreme Court." ${ }^{170}$ Four years later, while serving as a law professor at Yale, Taft began to lobby specific congressmen to draft a bill enabling the Court to reduce the numbers of appeals that the justices found lacked merit for review. ${ }^{171}$ The Court was, in fact, flooded by large numbers of what could be characterized as "garden variety" appeals that required the justices to review, thereby creating a large gap in time between the arrival of the appeal and the issuance of a determination. ${ }^{172} \mathrm{He}$ led a judicial effort to achieve greater control over not only the Court's docket, but also that of the lower federal courts, writing to Brandeis that the trials and appeals had become so voluminous that "justice became delayed into injustice." ${ }^{173} \mathrm{He}$ asked the justices to join a committee headed by the Chief Justice and including senior circuit justices to propose legislation to Congress. ${ }^{174}$

Although Taft strove for judicial efficiency, any analysis of Taft's drive to reform the federal and state judiciaries must take into account how the public perceived judges. The first three decades of the twentieth century witnessed an increase in impeachment trials against federal judges. In 1903, the Senate acquitted district court judge Charles H. Swayne after the House of Representatives had earlier determined that he was guilty of several improprieties, including abusing his contempt authority. ${ }^{175}$ Six years later, the House of Representatives conducted an investigation

166 CROWE, supra note 42, at 210.

167 CROWE, supra note 42, at 210.

168 Fish, supra note 118, at 103. In 1916, Taft called for a reduction in the Court's mandatory jurisdiction and to let the Justices vote on appeals on a certiorari basis. See Taft, supra note 79, at 15 .

169 CROWE, supra note 42, at 200.

170 UROFSKY, supra note 130 , at 458.

171 Felix Frankfurter and James m. Landis, The Business of the Supreme Court: A STUDY IN THE FEDERAL JUDICIAL SYSTEM 259 (2007).

172 Id.

173 Letter from William Howard Taft, Chief Justice, U.S. Supreme Court, to Louis Dembitz Brandeis, Associate Justice, U.S. Supreme Court (July 24, 1921) (on file in the Library of Congress).

174 Id.

17539 CONG. ReC. 3467 (1905); see also JAMes Ely JR., The ChiEF Justiceship of Melville W. FULLER, 1888-1910, at 50 (1995). Swayne had been accused of filing false claims against the government for reimbursements regarding his travel expenses. Id. 
into Lebbeus R. Wilfley, a federal judge presiding over a consular court in China, after a legislator accused him of anti-Catholic bias. ${ }^{176}$ In 1912, Congressman Victor Berger, who was later convicted under the Espionage Act, asked the House of Representatives to investigate Cornelius Hanford, a district court judge in Washington, and that same year, the House of Representatives issued articles of impeachment against Robert Wodrow Archbald, a judge on the U.S. Commerce Court. ${ }^{177}$ A majority of the Senate, but not the requisite two-thirds, voted to remove Archbald. ${ }^{178}$ The accusations against Archbald included "procuring financial favors from litigants who were successful in his court" as well as arbitrarily exercising his contempt power. ${ }^{179}$ In 1913, the House of Representative investigated Emory Speer, the district court judge for the Southern District of Georgia. ${ }^{180}$ Speer had not engaged in any unethical conduct, but he was irascible and publicly chastised litigants. ${ }^{181}$ Speer was a rarity in southern politics. Although he fought in the Confederate Army during the Civil War, when he was elected to Congress from Georgia in 1878, he aligned with the Republican Party as an "independent Democrat." 182 Republican President Chester Arthur nominated Speer as a federal judge, but Taft had a particular dislike of him. ${ }^{183}$ In 1918, Taft wrote to Senator Elihu Root, "Speer is a nuisance, a man of the most injudicial quality of mind, a man who is a constant irritation to the Bar, and a man who uses his judicial power to gratify his personal likes and dislikes." 184

Congressional investigations occurred well past Speer. Between 1914 and 1927, the House of Representatives investigated, in addition to Kennesaw Landis, Daniel Thew Wright on the Supreme Court of the District of Columbia, ${ }^{185}$ Alston Dayton on

176 Hearings Before the H. Comm. on the Judiciary, 60th Cong. (1908).

177 S. Doc. No. 62-1140, at 1682 (1913).

178 Conduct of Emory Speer: Hearings before a H. Subcomm. of the Comm. on the Judiciary, 63rd Cong. (1914).

179 Id.

180 For more information on Speer, see Timothy S. Huebner, Emory Speer and Federal Enforcement of the Rights of African Americans, 55 Amer. J. Legal Hist. 34 (2015).

$181 I d$. One of the aspects of Speer that Taft found appalling was that Speer openly supported Theodore Roosevelt's "Bull Moose" presidential candidacy in 1912. Taft, the Republican nominee campaigned against not only Woodrow Wilson, the Democrat Party nominee, but also Socialist Party candidate Eugene Debs and Roosevelt who had been his friend and benefactor. See id. at 61 n.69.

182 Id. at 39-40; see also Emory Speer Confirmed, N.Y. TimES, Feb. 18, 1885.

183 Huebner, supra note 180, at 47; see also Letter from William Howard Taft, Kent Professor of Law and Legal History, Yale Law School, to Elihu Root, U.S. Senator, New York (Jan. 12, 1915) (on file in the Library of Congress).

184 Letter from William Howard Taft, Kent Professor of Law and Legal History, Yale Law School, to Elihu Root, United States Senator, New York (Jan. 12, 1915) (on file in the Library of Congress). Taft also acknowledged that Speer was "a man of ability" but added "he has done things on the bench that are most improper." Id.

185 Clarence Cannon, Cannon's Precedents of the House of Representatives of the United STATES 553 (1921). 
the Northern District of West Virginia, ${ }^{186}$ William E. Baker on the Northern District of West Virginia, ${ }^{187}$ George English in the Eastern District of Illinois, and Frank Cooper on the Northern District of New York. ${ }^{188}$ Thus, by the time of Tumey, public confidence in the federal judiciary had been encumbered by number of well-publicized scandals. ${ }^{189}$

In light of these investigations, it is unsurprising that late nineteenth- and early twentieth-century politics included angry attacks on the fairness of the nation's courts. Senator George Norris of Nebraska articulated the beliefs of many Americans in 1912 when he argued that the United States possessed two systems of courts, "one for the wealthy and one for the poor." 190 That year, Norris led the House of Representatives in the prosecution of Archbald. ${ }^{191}$ Norris' criticism of the federal judiciary angered Taft, and throughout his presidency and judicial tenure, Taft expressed his dislike of Norris, but he understood that there existed a potential for due process weaknesses in the nation's courts at all levels. For instance, in 1914, Taft warned the American Bar Association:

The agitation with reference to the courts, the general attacks upon them, the grotesque remedies proposed by the recall of judges and recall of judicial decisions, and the resort of demagogues to the unpopularity of the courts as a means for promoting their own political fortunes, all impose on us as members of the bar and upon judges of the courts and legislatures, the duty to remove ... grounds for just criticism of our judicial system. ${ }^{192}$

One means by which Taft sought to counter criticism in the judiciary was to create a uniform code of ethics for judges. A code of ethics, in hindsight, was overdue. In 1908, the American Bar Association published its first canons of professional ethics

186 See Hearings Before the H. Comm. on the Judiciary, Subcomm. Designated to Investigate Charges Against Judge Alston Dayton Serial 28, 63rd Cong. (1915). Dayton had served in Congress as a West Virginia representative from 1895-1906. Theodore Roosevelt appointed him to the bench in March, 1905. Dayton had represented the Baltimore and Ohio Railroad while serving in Congress and one of that corporation's senior officials had threatened John J. Jackson, an elderly federal judge with impeachment proceedings through chosen congressmen if he did not retire. Not surprisingly, the House of Representatives impeachment inquiry found that Dayton had participated in this scheme. See id. at 954.

187 See Hearings Before the H. Comm. on the Judiciary, Subcomm. Designated to Investigate Charges against Judge William Baker, 68th Cong. (1924).

188 See H.R. Doc. No. 68-145 (1926).

189 For publicity on the impeachment process, see Connected with Probe of Hanford, Seattle Star, Feb. 15, 1913; Hanford Resigns: No Impeachment by Agreement with Committee Federal Judge Withdraws Under Fire, N.Y. TIMES, July 23, 1912; House Committee Says Impeach Judge Swayne, N.Y. Times, Mar. 26, 1904.

190 Charges Against Hon. Frank Cooper, U.S. Dist. Judge for the Northern. Dist. of N.Y.: Hearings Before the H. Comm. on the Judiciary, 69th Cong. (1927).

191 George W. Norris, Fighting Liberal: The Autobiography of George W. NORRIS 122 (1945).

192 FISH, supra note 118, at 17. 
for all attorneys. ${ }^{193}$ It took sixteen years for the Association to issue its Cannons of Judicial Ethics after a two-year process in which Taft served as the chairman of the committee authoring the cannons. ${ }^{194}$ Taft recognized that the states would not be bound by a national ethics code, but in the hopes of national acceptance, he appointed Robert von Moschzisker, a justice on Pennsylvania's supreme court, and Leslie Cornish, the chief justice of Maine's supreme court, to the committee. ${ }^{195}$ The thirtysix individual cannons that the bar association issued were a non-binding guidepost to govern the conduct of federal and state judges, but there are clear indicators for Taft's expectations of judicial impartiality which exceeded the narrow issues before the Court in Tumey.

Although Taft wanted to promote judicial integrity and public confidence in the judiciary, he did not abandon the idea of a jurisprudential test for judicial appointments. In 1922, Taft wrote to Elihu Root that he intended to meet with President Harding to convince him to appoint Henry Stimson to the Supreme Court. ${ }^{196}$ Taft went on to claim that Woodrow Wilson had appointed Brandeis and Clarke to "reduce the importance of the Constitution and advance a progressive agenda." $\mathrm{He}$ also urged, however, that "reactionary men" like McReynolds were an equal danger to individual rights and concluded, "We need men who are liberal but who believe that the corner stone of our civilization is in the proper maintenance of the guarantees of the Fourteenth Amendment and Fifth Amendment." 197 In 1926, Taft wrote to his brother Horace, "The truth is that McReynolds is quite unprincipled in his method of stating cases. He does not state them truthfully." 198

\section{THE “TAFT COURT” AND THE JUDICIAL CONTEMPT AUTHORITY}

The judicial authority to find a person guilty of contempt, including the power to sentence an offender to a fine and imprisonment, is not expressly stated in the Constitution's text. Moreover, the judiciary's contempt authority enables some of the very ends that the Fifth and Sixth Amendments prohibit the Executive Branch from

193 Editorial, Judicial Ethics, 50 A.B.A. J. 840 (1964).

194 Andrew J. Lievense \& Avern Cohn, The Federal Judiciary and the ABA Model Code: The Parting of the Ways, 28 Just. Sys. J. 273 (2007); see also William H. Taft, Final Rep. and Proposed Canons of Judicial Ethics, 9 A.B.A. J. 449 (1923).

195 Letter from William Howard Taft, Chief Justice, U.S. Supreme Court, to Charles Burlingham (Dec. 5, 1922) (on file in the Library of Congress). Taft, however, was not enamored with Judge Moschziker and on learning that a senator had asked President Harding to consider Moschzisker for a Supreme Court nomination, he wrote to Burlingham, "I don't think that his reputation as a lawyer and a judge in Pennsylvania is so high as to lead the President to select him. His background is political rather than professional and judicial." Id.

196 Letter from William Howard Taft, Chief Justice, U.S. Supreme Court, to Elihu Root, President, Carnegie Endowment for International Peace (Dec. 21, 1922) (on file in the Library of Congress). In this letter Taft also disparaged future justice, Felix Frankfurter. Taft wrote, "I never liked Frankfurter, and have continued to dislike him the more I have known him. Indeed the only thing I know against Stimson is his good opinion of Frankfurter." Id.

197 Id.

198 Letter from William Howard Taft, Chief Justice, U.S. Supreme Court, to Horace D. Taft, brother of William Howard Taft (Nov. 4, 1926) (on file in the Library of Congress). 
accomplishing — namely, the loss of liberty or property without a trial by jury. ${ }^{199}$ The judicial power to adjudge a witness, juror, spectator, or attorney of contempt is significant, among myriad reasons, because certain contempt convictions are tantamount to a finding of criminal guilt. ${ }^{200}$ A judicial finding of criminal contempt, coupled with a punitive sentence, is designed to "preserve the power and vindicate the authority of the courts." 201 A civil contempt, in opposite, is designed to protect the legal rights of litigants. ${ }^{202}$ There are safeguards, including the right of appellate review, to protect individuals from being adjudged guilty of either type of contempt. ${ }^{203}$ Additionally, in criminal contempt hearings, a person is presumed to be innocent, and guilt must be established beyond a reasonable doubt. ${ }^{204}$ As an aside, civil contempt hearings were historically structured similar to criminal contempt hearings but appear to have caused less concern to the Court, as there were few, if any, grants of appellate review against a civil contempt finding up through Taft's tenure. Given the Court's grant of review to these appeals from contempt findings, it is clear that Taft was concerned with the contempt powers of judges, and he was not satisfied with how the Court and Congress had historically shaped this power. A brief history of the Court and contempt decisions is important to provide context to Taft's efforts to curb the contempt authority.

In 1789, Congress conferred to the Judicial Branch the authority to find persons in contempt, including the power to sentence a person to a fine or imprisonment. ${ }^{205}$ Although the Constitution guarantees the right to trial by jury in criminal matters, from the beginning of the nation, this right was not thought to extend to contempt proceedings. ${ }^{206}$ In 1821, in Anderson v. Dunn, the Court determined that while the

199 See, e.g., Ex parte Terry, 128 U.S. 289, 302 (1888); Ex parte Cuddy, 131 U.S. 280, 28384 (1889).

200 Gompers v. Bucks Stove \& Range Co., 221 U.S. 418, 441 (1911). Bucks Stove \& Range, labor leader Samuel Gompers, and the American Federation of Labor ignored a judicial injunction to cease publishing documents that encouraged readers to boycott a corporation. The Court, in a decision authored by Justice Lamar, determined that a civil contempt arises when the judge issues an order for a party to accomplish and act and the imprisonment which results from the failure or refusal to conform with the act, is to convince the party to conform or remain in prison. Id. at 442. Put another way, Lamar penned into the decision, "If imprisoned . . . he carries the keys of his prison in his own pocket. He can end the sentence and discharge himself at any moment by doing what he had previously refused to do." Id.

201 Id. at 441.

202 Eilenbecker v. Dist. Court, 134 U.S. 31, 36 (1890). However, in 1914, Congress enacted the Clayton Act which permitted jury trials in certain contempt proceedings involving picketing and boycotting activities by unions. See, e.g., Michaelson v. United States ex rel. Chi., St. Paul, \& Omaha Railway Co., 266 U.S. 42, 62-63 (1928); Bessette v. W.B. Conkey Co., 194 U.S. 324, 328 (1904); In re Debs, 158 U.S. 564, 594 (1895).

203 Myers v. United States, 264 U.S. 95 (1924).

204 Gompers v. Bucks Stove \& Range Co., 221 U.S. 418, 444 (1911).

205 Establishment of the Judicial Courts of the United States, ch. 20, 1 Stat. 73 (1789).

206 U.S. ConST. art. III, § 2, cl. 3 ("The Trial of all Crimes, except in Cases of Impeachment, shall be by Jury; and such Trial shall be held in the State where the said Crimes shall have been committed; but when not committed within any State, the Trial shall be at such Place or Places as the Congress may by Law have directed."); U.S. CONST. amend. VI ("In all criminal 
Constitution does not specifically vest Congress with the authority to punish for contempt, the authority to do so was readily apparent by implication. ${ }^{207}$ Dunn arose from a challenge to the House of Representatives finding a citizen in contempt. ${ }^{208}$ Important to the decision, however, was that the Court observed that, although the issue on appeal had to do with the Legislative Branch's contempt power, the federal courts were statutorily vested with the authority to find persons in contempt. ${ }^{209}$ Moreover, the justices maintained that even if the statute did not exist, the power would remain. ${ }^{210}$ One can speculate that the justices involved in architecting this decision placed language regarding judicial contempt power to remind the political branches of government that such power was inherent in an independent judiciary.

From 1789 through John Quincy Adams' presidency in 1825, it appeared that the federal judiciary's contempt authority had few defined limits. In 1826, the House of Representatives undertook impeachment hearings against Judge James Peck, a U.S. District Court Judge from Missouri. ${ }^{211}$ Peck earlier had adjudged an attorney named Luke E. Lawless guilty of contempt after Lawless published a newspaper article critical of one of Peck's decisions regarding an antiquated Spanish land-claim. ${ }^{212}$ Peck sentenced Lawless to one day in prison and an eighteen-month suspension from the practice of law. ${ }^{213}$ At the time of Lawless' article, Peck had already issued a ruling, and neither party had undertaken an appeal. ${ }^{214}$ Lawless argued to Peck that because the district court no longer had jurisdiction over the contested land-claim issue, Peck no longer had jurisdiction to hold a person in contempt who criticized the decision. ${ }^{215}$ It took until March 23, 1830 for the House of Representatives to recommend that the Senate find Peck guilty of "high crimes or misdemeanors." 216 The Senate ultimately

prosecutions, the accused shall enjoy the right to a speedy and public trial, by an impartial jury of the State and district wherein the crime shall have been committed, which district shall have been previously ascertained by law, and to be informed of the nature and cause of the accusation; to be confronted with the witnesses against him; to have compulsory process for obtaining witnesses in his favor, and to have the Assistance of Counsel for his defence.").

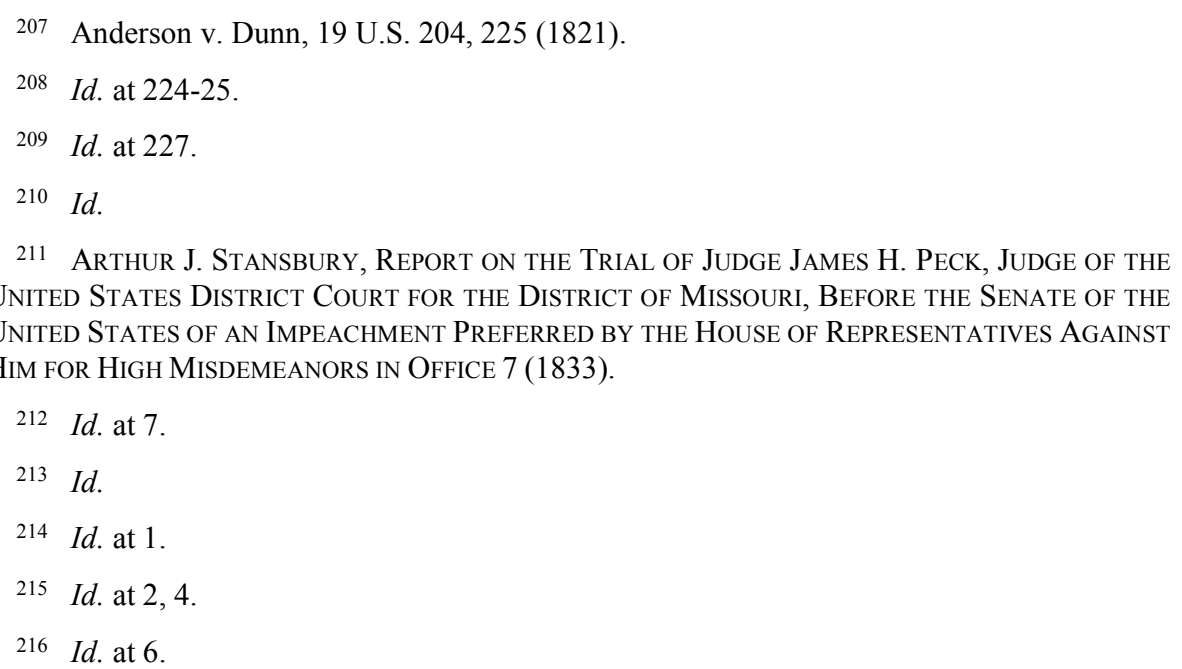


acquitted Peck by a vote of twenty-one to twenty. ${ }^{217}$ On the other hand, Peck's overreach in his authority resulted in the Judicial Act of $1831 .{ }^{218}$

In response to Peck's action, Congress limited the contempt authority of federal judges to punish misbehavior in "the presence of the federal courts or so near thereto as to obstruct the administration of justice." 219 The 1831 Act also enabled a judicial finding of contempt against a person who threatened or attempted to influence an officer of the court, juror, or witness. ${ }^{220}$ In 1873, the Court in Ex Parte Robison ${ }^{221}$ upheld the 1831 Act as it applied to the circuit courts, but the decision left open the question as to whether Congress possessed the authority to constrain the Court's contempt authority. ${ }^{222}$ Robinson arose from a U.S. District Court's disbarment of an attorney during a contempt hearing. ${ }^{223}$ The federal judge had ordered a witness to be present for a grand jury, but the witness remained absent. ${ }^{224} \mathrm{~J}$.S. Robinson, an attorney named in the decision, had permitted the witness to remain in his office to avoid the judicial summons. ${ }^{225}$ The federal judge found Robinson guilty of criminal contempt and disbarred him. ${ }^{226}$ After granting a writ of mandamus, the Court, in a decision authored by Justice Stephen A. Field, unanimously determined that although the federal courts had the authority to both punish for contempt and to disbar an attorney by "striking the petitioner's name from the roll of attorneys," disbarment proceedings required a greater quantum of due process than a summary contempt proceeding. ${ }^{227}$ That is, a disbarment hearing required notice and the opportunity to mount a defense. ${ }^{228}$ Thus, unlike a contempt hearing which could be held immediately following the alleged contempt, a disbarment hearing could only occur after the attorney had been given a reasonable time to assemble a defense. In 1890, in Eilenbecker v. District Court of Plymouth County, the Court, in a decision authored by Justice Samuel Freeman Miller, determined that the Fourteenth Amendment did not require a jury trial for a criminal contempt proceeding that resulted in a finding of guilt and an imprisonment for three months. ${ }^{229}$

217 Id. at 474.

218 Walter Nelles \& Carol W. King, Contempt by Publication in the United States, 28 Colum. L. ReV. 401, 426-30 (1928).

219 Proceedings in the Senate of the United States in the Matter of the Impeachment of Charles Swayne: Judge of the Dist. Court of the United States in and for the Northern Dist. of Florida, 58th Cong., 757 (1905).

220 Id.

221 Ex parte Robinson, 86 U.S. 505 (1873).

222 Id. at 510-11.

223 Id. at 511.

224 Id. at 506.

225 Id. at 507.

226 Id. at 508.

227 Id. at 512-13.

228 Id.

229 Eilenbecker v. Dist. Ct. of Plymouth Cty., 134 U.S. 31, 32, 38 (1890). 
In 1888, the Court issued Ex Parte Terry, ${ }^{230}$ a decision which originated in a habeas writ. On September 3, 1888, a woman named Sarah Althea Terry engaged in disorderly conduct in the United States District Court for California. ${ }^{231}$ In response, the presiding judge ordered the marshal to restrain Ms. Terry, who in turn assaulted the marshal. ${ }^{232}$ Ms. Terry's husband, an attorney named David Terry, also assaulted the marshal. ${ }^{233}$ The presiding judge then found David Terry guilty of contempt and sentenced him to six months confinement. ${ }^{234}$ Problematic to the issue was that Justice Stephen Field was the presiding judge, albeit acting in his capacity as a circuit judge rather than as a justice of the Court. ${ }^{235}$ In his circuit decision, Field noted that Terry had brought a knife into the courtroom in violation of the law as well. ${ }^{236}$ Also problematic to the decision was the fact that Terry had been the chief justice of the California Supreme Court prior to Field serving on that court, and the two men had been long-time antagonists. ${ }^{237}$

Justice John Harlan authored the majority opinion in which he recognized the inherent authority of the federal circuit courts to punish contempts. ${ }^{238}$ Harlan next applied a jurisdictional test to determine whether the Court could issue the writ. ${ }^{239}$ Essentially, Harlan framed the issue as to whether the circuit judge had the authority to order Terry's imprisonment and not whether the term of six months was reasonable. ${ }^{240}$ Terry argued that the contempt order was made in his absence, that the court never provided him notice, and that he was not given the opportunity to defend himself. ${ }^{241}$ Field had issued the contempt order after Terry was arrested but before he was brought back into the courtroom. ${ }^{242}$ However, in this instance, the Court denied the habeas writ on the basis that in issuing the contempt determination and sentence, "the judicial eye witnessed the act, and the judicial mind comprehended all the circumstances of aggravation, provocation, or mitigation; and, the fact being thus

\footnotetext{
230 In re Terry, 128 U.S. 289 (1888).

231 Id. at 298.

232 Id.

233 Id.

234 Id.

235 In re Terry, 36 F. 419, 420 (C.C.N.D. Cal. 1888).

236 Id. at 419.

237 David Schultz, Field, Stephen 1816-1899, in 2 ENCYCLOPEDIA OF THE SUPREME CourT OF THE United STATES 207, 208 (David S. Tanenhaus ed., 2008). Ultimately Terry attempted to assassinate Field, but was killed by Field's protecting United States Marshal before accomplishing the act. See In re Neagle, 135 U.S. 1, 5 (1890).

238 In re Terry, 128 U.S. at 302.

239 Id. at 306.

$240 \quad I d$.

241 Id. at 306.

242 Id. at 311.
} 
judicially established, it only remained for the judicial arm to inflict proper punishment." 243

In 1906, in United States v. Shipp, ${ }^{244}$ the Court, in a decision authored by Justice Holmes, unanimously held that it not only possessed the authority to determine the extent of its own jurisdiction, it also determined that it possessed jurisdiction to hold individuals in contempt. In February 1906, a Tennessee state criminal trial found "Johnson, a colored man," guilty of "rape upon a white woman" and sentenced him to death. ${ }^{245}$ Johnson's attorneys appealed to the United States Court of Appeals for the Sixth Circuit for a writ of habeas corpus. ${ }^{246}$ Although the Court of Appeals denied a writ, Justice Harlan ordered the state to "stay" Johnson's execution until the Court could determine the merits of the habeas appeal. ${ }^{247}$ Shortly after Harlan's order, a sheriff colluded with white citizens to enable a mob to murder Johnson. ${ }^{248}$ In response, the justices unanimously agreed to hold a contempt trial against the sheriff, the jailer, and several other officials including the state trial judge. ${ }^{249}$ These men appealed against the Court's assertion of its contempt jurisdiction. ${ }^{250}$ The Court resoundingly determined that it possessed jurisdiction to hold persons in contempt regarding any issue that it possessed jurisdiction over, and, because the Court determined its own jurisdiction, the acts or omissions of the persons responsible for Johnson's murder could be found contemptuous. ${ }^{251}$ When read to its logical extent, one could find that the Court implied that it possessed almost unlimited contempt authority.

Contempt appeals continued when Taft became Chief Justice. In 1923, the Court determined in Craig v. Hecht that a single appellate judge could not unilaterally reverse a district court judge's finding of contempt. ${ }^{252}$ In October 1919, Charles Levy Craig, New York City's comptroller, published an open letter to the city's public service commissioner disparaging United States District Court Judge Julius Mayer during a trial in which Craig was a party. ${ }^{253}$ For a two-year period, Mayer afforded Craig an opportunity to retract his letter, but Craig refused to do so, and Mayer ordered the United States Marshal, William C. Hecht, to arrest Craig for the purpose of holding

\footnotetext{
243 Id. at 312.

244 United States v. Shipp, 203 U.S. 563, 573 (1906).

245 Id. at 571.

246 Id. Johnson credibly alleged that a mob had intimidated his attorneys and that AfricanAmericans had been excluded from service on the jury. Id. For the later decision in this case, see United States v. Shipp, 214 U.S. 386 (1909).
}

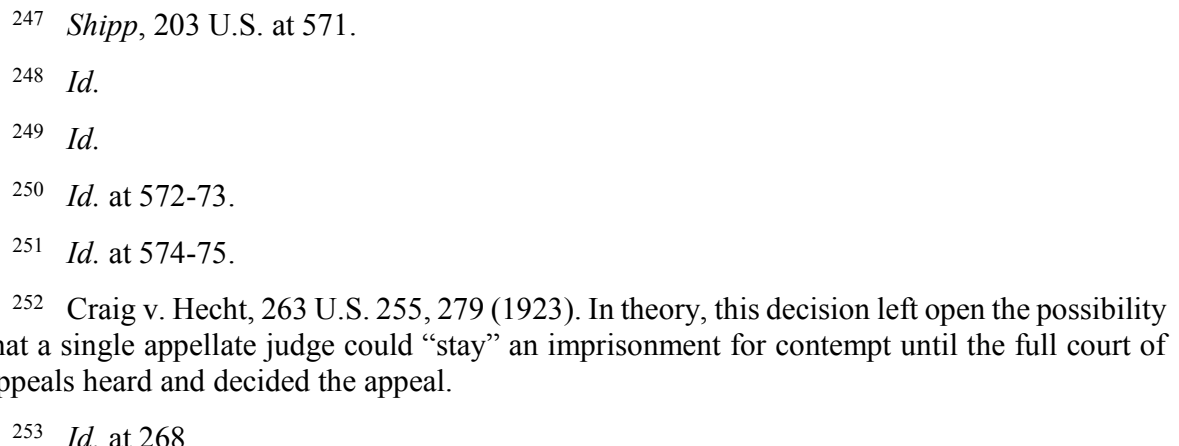


a contempt trial. ${ }^{254}$ Ultimately, Mayer sentenced Craig to sixty days in jail and a fine, but Martin Manton a judge on the Court of Appeals for the Second Circuit issued a writ of habeas ordering Craig's release. ${ }^{255}$ The Second Circuit reversed Manton and determined that a circuit court judge could not, while acting singly, overturn a contempt decision by a grant of habeas on the basis of a writ of error. ${ }^{256}$ When Craig's appeal came to the Court, Justice McReynolds, rather than Taft, authored the majority decision in which the justices determined that a circuit court judge serving in a singular capacity did not possess either the statutory or inherently constitutional authority to issue a writ of habeas over a person held in confinement as a result of contempt decision. ${ }^{257}$ The one exception to this rule would occur when the originating district court did not possess jurisdiction over the person held in contempt. ${ }^{258}$ Because Mayer possessed contempt jurisdiction over Craig, the Court concluded that Manton had exceeded his authority in granting habeas. ${ }^{259}$ Holmes, with Brandeis joining, dissented from the decision for two reasons. First, Holmes argued that Manton was within his authority to grant Craig habeas because Craig had been deprived of his liberty. ${ }^{260}$ Second, and equally importantly, Holmes considered that the First Amendment's guarantee of freedom of speech served as one measure to show that it was Mayer who exceeded his authority. ${ }^{261}$

Taft authored a concurrence for the purpose of reiterating that parties to a former litigation as well as their counsel possessed a limited right to criticize a judge without the fear of a contempt finding. ${ }^{262}$ Under this "doctrine," while litigation was ongoing, a party could comment on the proceedings as long as the statements were not of a nature to undermine the fairness of the trial. Taft stressed that once a case had been fully adjudicated, the parties to the case were free to publicly criticize the judge. ${ }^{263}$

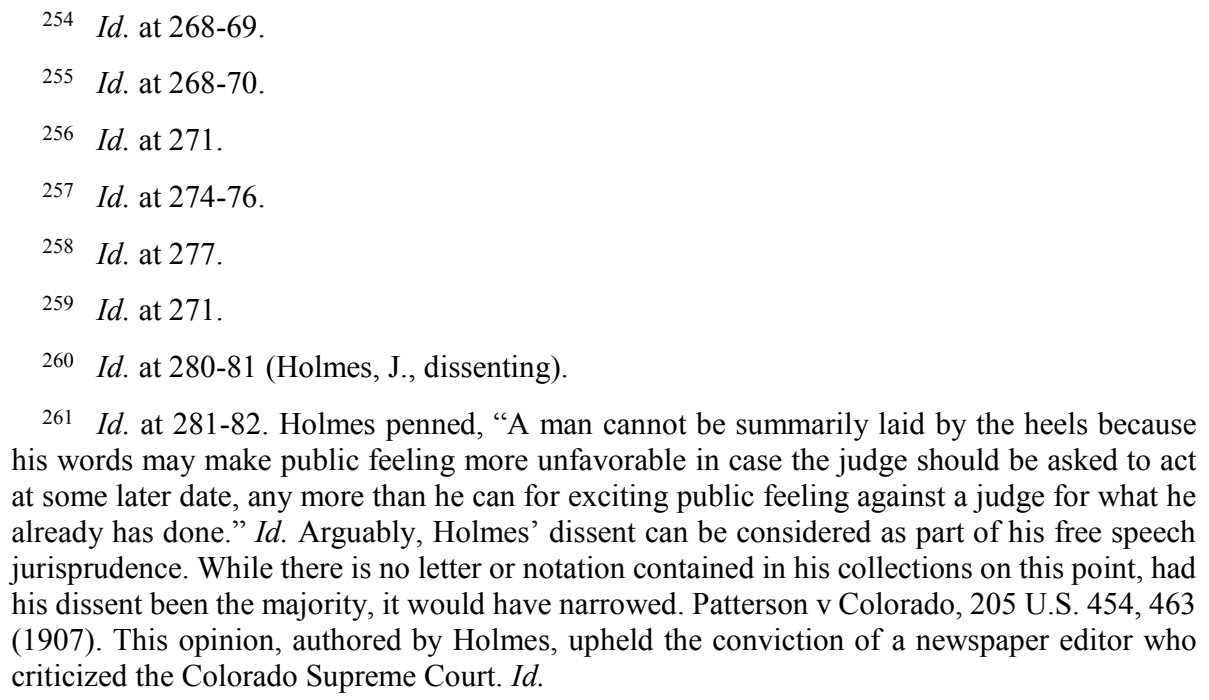

261 Id. at 281-82. Holmes penned, "A man cannot be summarily laid by the heels because his words may make public feeling more unfavorable in case the judge should be asked to act at some later date, any more than he can for exciting public feeling against a judge for what he already has done." Id. Arguably, Holmes' dissent can be considered as part of his free speech jurisprudence. While there is no letter or notation contained in his collections on this point, had his dissent been the majority, it would have narrowed. Patterson v Colorado, 205 U.S. 454, 463 (1907). This opinion, authored by Holmes, upheld the conviction of a newspaper editor who criticized the Colorado Supreme Court. Id.

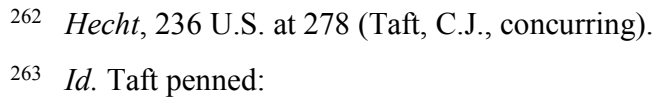

It is of primary importance that the right freely to comment on and criticize the action, opinions and judgments of courts and judges should be preserved inviolate; but it is also essential that courts and judges should not be impeded in the conduct of judicial business by publications having the direct tendency and effect of obstructing the 
Taft was silent on a generalized right to criticize a judge prior to any known litigation, such as in the case of judicial appointments and elections, in all likelihood because such questions were not at issue. Taft also used his concurrence to criticize Craig and his attorneys for convincing Manton to rely on an outdated statute to exceed his judicial authority in overturning Craig's conviction. ${ }^{264}$ Like Victor Berger's appeals against Landis, the New York Times reported on Craig's and Mayer's conduct. ${ }^{265}$ According to Alpheus Mason, one of Taft's early biographers, Taft later lobbied President Calvin Coolidge to pardon Craig. ${ }^{266}$ On the other hand, Taft did not hold Craig in high esteem. In 1928, Taft wrote to his son Robert Taft, "Craig is the man who got into contempt of the court in New York, and we had to sustain the commitment. He is a most cantankerous fellow." 267

enforcement of their orders and judgments, or of impairing the justice and impartiality of verdicts.

If the publication criticizes the judge or court after the matter with which the criticism has to do has been finally adjudicated and the proceedings are ended so that the carrying of the court's judgment cannot be thereby obstructed, the publication is not contempt and cannot be summarily punished by the court however false, malicious or unjust it may be. The remedy of the judge as an individual is by action or prosecution for libel. If, however, the publication is intended and calculated to obstruct and embarrass the court in a pending proceeding in the matter of the rendition of an impartial verdict, or in the carrying out of its orders and judgment, the court may, and it is its duty to protect the administration of justice by punishment of the offender for contempt.

Id. Taft's reasoning was not unique. In 1887 the Indiana Supreme Court held in Cheadle v. State that while a citizen was free to criticize a judge after a trial had ended, speech that was calculated to, or had the potential to affect the outcome of the trial could be the basis for a contempt conviction. Cheadle v. State, 11 N.E. 426, 431 (1887). In 1890, the California Supreme Court expanded this doctrine to include newspaper coverage of a trial. See, e.g., Ex parte Barry, 85 Cal. 603, 608 (1890). Barry appears to have been significantly narrowed, if not eviscerated by the Court in Pennekamp v. State of Florida, 328 U.S. 331, 349 (1946).

\section{Hecht, 236 U.S. at 279. Taft instructively wrote:}

Instead of pursuing this plain remedy for injustice that may have been done by the trial judge and securing by an appellate court a review of this very serious question on the merits, they sought by applying to a single judge of only coordinate authority for a writ of habeas corpus to release the petitioner on the ground that the trial judge was without jurisdiction to make the decision he did. This raised the sole issue whether the trial judge had authority to decide the question, not whether he had rightly decided it.

Id.

265 Craig Loses Appeal From Jail Sentence: Higher Court Holds Judge Manton Had No Power to Issue Habeas Corpus Writ, N.Y. Times (May 23, 1923), http:/query.nytimes.com/mem/archivefree/pdf?res=940DE2D91339E133A25750C2A9639C946395D6CF; Craig Contempt Case Moves Ahead, N.Y. TIMES (Mar. 20, 1923), http://query.nytimes.com/mem/archivefree/pdf?res=9405E1DB1639EF3ABC4850DFB5668389639EDE.

266 Alpheus Thomas Mason, William Howard Taft: Chief Justice 144 (1964).

267 Letter from William H. Taft, Chief Justice, U.S. Supreme Court, to Robert A. Taft, son of William H. Taft (May 6, 1928) (on file in the Library of Congress). Craig seems to have had a combative history with judges. In 1919, a New York state trial judge held him in contempt. See Court Fines Craig $\$ 250$ for Contempt, N.Y. TIMES (Dec. 9, 1919), 
In 1925, the Court issued two decisions further shaping the judiciary's contempt authority. By the time Taft became chief justice, he was concerned with two aspects of the judicial contempt authority that he believed, if left unchecked, could enable a tyrannical judiciary, particularly in light of Shipp.

The first decision arose from a challenge to the President's power to pardon a convicted person. The Constitution expressly grants to the President the authority to pardon a person convicted of crimes, and since the nation's founding, presidents had pardoned persons judicially convicted of contempt. ${ }^{268}$ On November 24, 1920, Judge Kenesaw Landis issued an injunction against Philip Grossman, a Chicago barkeep. ${ }^{269}$ The injunction was basically a judicial order to Grossman to desist from serving alcohol in violation of the Volstead Act, and Landis issued it at the behest of the Department of Justice. ${ }^{270}$ Grossman violated the injunction and continued to sell liquor. ${ }^{271} \mathrm{He}$ was prosecuted for contempt, found guilty, and sentenced to a year in prison and a one thousand dollar fine. ${ }^{272} \mathrm{He}$ remained free from prison on bail while he appealed his conviction. ${ }^{273}$ In December 1923, President Coolidge commuted Grossman's sentence to the fine, and after Grossman paid the fine, Coolidge pardoned him. ${ }^{274}$ The Chicago Daily Tribune, excoriated Coolidge for the pardon. ${ }^{275}$ In response to the pardon, United States District Court Judge James Herbert Wilkerson, who had replaced Landis after Landis resigned his judgeship to become the fulltime commissioner of baseball, ordered Grossman into confinement. ${ }^{276}$ Grossman challenged Wilkerson's order in district court, and a two-judge panel consisting of Judge George Albert Carpenter and Wilkerson determined that the judicial contempt power was not "subject to the good will of the executive." 277 Although Wilkerson and Carpenter were confronted with an issue of first impression, their decision represented a significant judicially imposed constraint on the Executive Branch. ${ }^{278}$

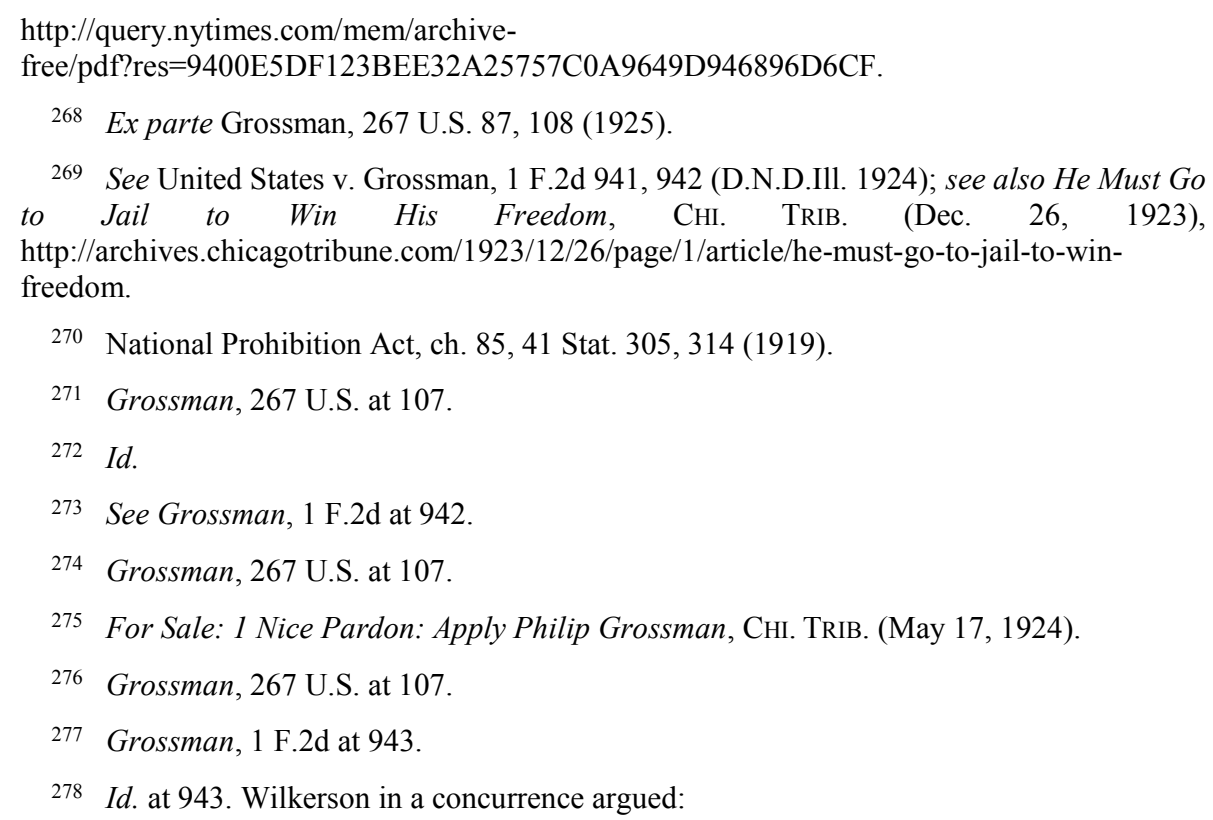

If the President has the power to grant the pardon in this case, what becomes of the sanctity of decrees against confiscatory acts of the agents of government, state and national? What becomes of injunctive orders under the interstate commerce, antitrust 
On May 2, 1924, Landis appeared before the Senate's Extraordinary Investigation Committee. ${ }^{279}$ During his testimony, Landis disavowed any knowledge that he provided a newspaper the following quote: "Just why may we expect $\$ 1,800$ a year probation agents to stand up four-square for law enforcement with the President granting a pardon." 280 However, in his personal correspondences, it is clear that he permitted an interview with the Hearst International Newspaper Syndicate on February 6, 1924, and criticized Coolidge's pardon to Grossman. ${ }^{281}$ Initially, the Senate

and kindred statutes? What becomes of the authority of the courts to protect the citizen in the exercise of the rights guaranteed to him by the Constitution, against irreparable injury to life and property? It was well said that the power to tax is the power to destroy; it is just as true that the power to pardon for contempt is the power to destroy judicial authority.

Id. at 954. Of note, Taft later became critical of Carpenter's judicial acumen. He asked Judge Evan Albert Evans, a Woodrow Wilson appointee on the Court of Appeals for the Seventh Circuit to investigate Carpenter. See Letter from William H. Taft, Chief Justice, U.S. Supreme Court, to Evan A. Evans, Judge, U.S. Court of Appeals for the Seventh Circuit (Apr. 9, 1928) (on file in the Library of Congress). Evans responded:

Since 1916 I have heard almost constant complaints about Carpenter's work. These came from district judges, the district attorney, and numerous trial lawyers. These complaints generally include indifference and inattention to duties and an absence of required industry. The criticisms have increased each year. Last fall it nearly reached the boiling point over which the associate district attorney made oral complain to Judge Alschuler. I am satisfied the complaints are justified ... Judge Carpenter does not seem to cooperate. He has a marked aversion for critical cases and common-law actions. The parties complain that he only sits a half day when he has a jury trial and often an hour late when he opens his court.

Letter from Evan A. Evans, Judge, U.S. Court of Appeals for the Seventh Circuit, to William H. Taft, Chief Justice, U.S. Supreme Court (Apr. 5, 1928) (on file in the Library of Congress).

279 Investigation of Honorable Harry M. Daughtery, Formerly Attorney Gen. of the U.S., Hearings Before the Select Comm. on Investigation of the Attorney Gen., U.S. S., Sixty-Eighth Cong., First Session, Pursuant to S. Res 157, Directing a Comm. to Investigate the Failure of the Attorney Gen. to Prosecute or Defend Certain Criminal and Civil Actions, Wherein the Gov't is Interested, 68th Cong. 935-55 (1924) [hereinafter Hearings] (statement of Kenesaw M. Landis).

280 Hearings, supra note 279, at 935-55; PIETRUSZA, supra note 59, at 218. Newspapers carried Landis' testimony, and typical of headlines was the Reading Eagle's Saloon Man's Pardon Puzzles Judge Landis, ReAding Eagle, May 2, 1924, at 30; see also Senate Calls Landis in Sift of Rum Pardon: Ex Judge to Tell of Grossman's Case, CHI. TRIB. (Apr. 30, 1924); Daugherty is Target in Plan of Senators for Criminal Action, Toledo Blade (May 8, 1924).

281 Letter from Kenesaw M. Landis, Judge, Northern District of Illinois, to Louis R. Glavis, Employee, U.S. Dept. of the Interior (Feb. 6, 1924) (on file with the Kenesaw Landis Papers in the Chicago Historical Society). Landis wrote to Glavis,

It is the pulling and hauling process by political gentlemen in a position to elect delegates to a convention that will choose a successor to the official who temporarily happens to be exercising the pardon power that discredits the whole thing ... You will understand these observations are only by way of suggestions to you and are not to be quoted. This is solely because when I get ready to talk about this fraud again, I shall want to choose my own language. I can only repeat to you that I think the Grossman pardon was dishonestly induced. 
committee was not focused on Coolidge's pardon to Grossman, although Landis attempted to steer the committee in that direction. Rather, the committee centered its attention on corruption in the Justice Department under Attorney General Harry Daugherty. ${ }^{282}$ Taft became furious with Landis over his testimony because he believed that no judge, or former judge, should openly criticize the sitting President over an issue the judge had presided over. ${ }^{283}$ Interestingly, Coolidge distrusted Attorney General Daugherty and had asked a willing Taft to privately encourage Daugherty to resign. ${ }^{284}$

In Ex Parte Grossman, Taft authored a unanimous decision in which the Court determined that the presidential "pardon power" applied to federal criminal contempt convictions. ${ }^{285} \mathrm{He}$ observed that presidential pardons had been issued against contempt convictions during the previous eighty-five years without appeal. ${ }^{286}$ However, Taft realized that this fact alone was hardly dispositive to the constitutional issue in front of the Court, and he reached to British common law predating the Constitution regarding the monarchal authority to pardon contempts for the purpose of articulating that the presidential power to pardon was simply an extension of British practice. ${ }^{287}$ Taft then turned to the Constitutional Convention of 1787 in which the participants determined that the only bar to the exercise of the pardoning power was in regard to impeachments. ${ }^{288}$ Led by Taft, the Court decided that all other "offenses against the United States" were within the scope of the power to pardon. ${ }^{289}$ Taft conceded, as Wilkerson and Carpenter had pointed out, that the term "crimes and misdemeanors" were clarified by the Court in 1812 in United States v. Hudson and Goodwin ${ }^{290}$ to mean only those acts which Congress prohibited and that had a punishment affixed by statute to the prohibition. ${ }^{291}$ However, he countered that "offenses against the United States" were not exclusive to crimes and misdemeanors because the contempt authority had evolved since the Constitution's enactment. ${ }^{292}$

To Taft, the most important aspect to the decision appears to have been a question relating to the Constitution's separation of powers. Wilkerson and Carpenter had concluded that the Executive Branch's exercise of the pardon power undermined the

Id. Although there appears to be no evidence of collusion between Landis and Hearst, it does appear suspicious that Hearst's newspapers had attacked Taft at this time.

282 See generally Hearings, supra note 279, at 935-55.

283 PIETRUSZA, supra note 59, at 215.

284 William A. Cook, King of the Bootleggers: A Biography of George Remus 85 (2008). Taft had been friendly with Daugherty for several years and Daugherty often served as Taft's "conduit" to Harding.

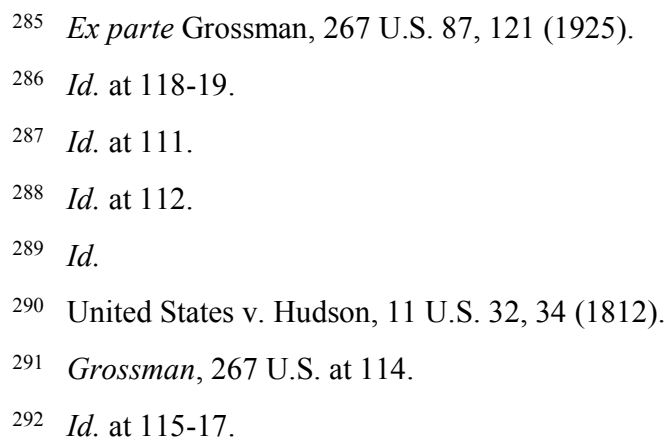


Judicial Branch. ${ }^{293}$ Taft countered that the lifetime tenure of judges and the constitutional prohibition against diminishing judicial salaries served as a check against arbitrary presidential action. ${ }^{294}$ Tellingly, after noting other constitutional checks against each of the federal government's branches, he emplaced into the decision the following phrase:

[W]hile the Constitution has made the Judiciary as independent of the other branches as is practicable, it is, as often remarked, the weakest of the three. It must look for a continuity of necessary cooperation, in the possible reluctance of either of the other branches, to the force of public opinion. ${ }^{295}$

Taft cited no case law for this statement, but it was a strong indication that he believed the Judicial Branch should be constrained in using its authority. In contrast to its excoriation of Coolidge, the Chicago Daily Tribune favorably reported on the decision with the headline "President Can Pardon Guilty of Contempt."296

Before the Court granted certiorari in Grossman, Taft spoke to the student body of Columbia University's law school. ${ }^{297}$ His speech, titled "Our Chief Magistrate and his Powers," reflected a book Taft first published in 1916, but was later published by the university in a significantly lengthened format. ${ }^{298}$ Although the speech centered on the President's authority as Commander in Chief, he analyzed the relationship between the judiciary's contempt authority and the President's authority to pardon:

There is a question whether the President's power of pardon extends to the case of one sentenced to imprisonment for contempt by a federal court ... It is objected that this power of contempt is used by the court to enforce his judgments and that if the President could intervene and paralyze the instrument in the hand of the Court to enforce its judgment, he would not be pardoning crime, but would be obstructing the Court in its administration of justice. ${ }^{299}$

Taft then evidenced how he would decide Grossman by articulating that in instances where a court issues a contempt sentence to "vindicate its own authority,"-e.g., a criminal contempt - the President had a constitutional power to issue a pardon. ${ }^{300}$

One day before hearing argument in Grossman, Taft complained to his daughter that, because of low judicial salaries, there were too many judges "who are failures in

\footnotetext{
293 Id. at 119.

294 Id.

295 Id. at 120.

296 President Can Pardon Guilty of Contempt, CHI. TRIB., Mar. 2, 1925, at 1.

297 William Howard Taft, The Presidency, It's Powers, Duties, Responsibilities, and Limitations: Our Chief Magistrate and His Powers (1915-16) (lectures by William Howard Taft during the winter session of 1915-16, also known as the Blumberg Lectures).

298 Id.; William Howard Taft, Our Chief Magistrate and His Powers (1916).

299 Id.

300 Id.
} 
the profession and who never would be thought of, but for the lack of real timber." ${ }^{301}$ Taft did not directly implicate Landis as part of the problem of judicial competency or a lack of ethics, but this is not surprising because Landis had already left the bench to become baseball commissioner. ${ }^{302}$ Taft placed this criticism alongside the comment that the Court had "heard some important cases, and we are going to hear some more in these coming weeks." ${ }^{303}$ Contemporaneously, he wrote to Senator Augustus Stanley of Kentucky, "While it was essential to give to the Court greater control over its own docket to determine cases of Constitutional importance, trust should also be given to the Court to police the judiciary." 304 Grossman reflects the Court exercising a "policing power" over the lower judiciary's assertions of its own authority, and it is, at a minimum, circumstantially coincidental that Taft, as previously noted in regarding the establishment of a judicial conference, was at the same time trying to convince Congress that the Court had to play a greater role in regulating the federal judiciary. One week after listening to the arguments in Grossman, Taft informed his son Charles, "[The Court had] been pushing along through a docket of select cases and [has] had three very important constitutional questions put to us. One as to whether the President can pardon contempts under the Volstead Act." 305 He similarly expressed the constitutional importance of Grossman to his brother Horace and emphasized that the Volstead Act was not a constraint on the President's pardon authority. ${ }^{306}$

While the Court in Grossman recognized the existence of a constitutional check against contempts, in Cooke v. United States, ${ }^{307}$ the justices placed an implied constitutional constraint on the judicial contempt authority. Taft also authored the unanimous decision in Cooke, and it was issued almost contemporaneously with Grossman. ${ }^{308}$ Cooke arose from an appeal against a contempt conviction in the U.S. District Court for the Northern District of Texas. ${ }^{309}$ In 1923, Judge James C. Wilson

301 Letter from William Howard Taft, Chief Justice, U.S. Supreme Court, to Helen Herron Taft, wife of William Howard Taft (Nov. 30, 1924) (on file in the Library of Congress).

302 See supra note 69 and accompanying text.

303 Letter from William Howard Taft, Chief Justice, U.S. Supreme Court, to Helen Herron Taft, wife of William Howard Taft (Nov. 20, 1924) (on file in the Library of Congress).

304 Letter from William Howard Taft, Chief Justice, U.S. Supreme Court, to Augustus Stanley, U.S. Senator, Ky. (Dec. 5, 1924) (on file in the Library of Congress).

305 Letter from William Howard Taft, Chief Justice, U.S. Supreme Court, to Charles P. Taft, son of William Howard Taft (Dec. 7, 1924) (on file in the Library of Congress).

306 Letter from William Howard Taft, Chief Justice, U.S. Supreme Court, to Horace D. Taft, brother of William H. Taft (Dec. 7, 1924) (on file in the Library of Congress). The day before the Court issued Grossman, Taft complained to his son Robert that the Court was going to issue forty opinions and could only dedicate two minutes to the decision. Letter from William Howard Taft, Chief Justice, U.S. Supreme Court, to Robert Taft, son of William Howard Taft (Mar. 1, 1925) (on file in the Library of Congress).

307 Cooke v. United States, 267 U.S. 517, 537 (1925).

308 Id. Cooke was argued on March 20, 1925, and issued on April 13, 1925. Id. at 517. Grossman was argued on December 1, 1924, and issued on March 2, 1925. Ex parte Grossman, 267 U.S. 87, 87 (1925).

309 Cooke, 267 U.S. at 518. 
adjudged attorney Clay Cooke and his client, J.L. Walker, guilty of contempt. ${ }^{310} \mathrm{~J}$. Frank Norris - a leading minister on the side of Prohibition and against the teaching of evolution - had criticized Wilson for siding with "wets" against prohibitionists and the Ku Klux Klan in 1922.311 Walker was a defendant in a series of bankruptcy suits involving his grain storage company, and after losing the first case, Cooke attempted to have Wilson recuse himself from the other pending trials. ${ }^{312}$ Unlike Victor Berger, Cooke did not file a formal affidavit with the court and instead instructed Walker to deliver a personal letter to the judge. ${ }^{313}$ Cooke's letter was intemperate. He not only accused Wilson of bias against Walker, but also added, "I had believed that Your Honor was big enough and broad enough to overcome the personal prejudice against the defendant Walker, which I knew to exist, but I find that in this fond hope I was mistaken." 314

On February 26, 1923, Wilson directed the marshal to arrest both Walker and Cooke and commenced a criminal contempt proceeding. ${ }^{315}$ Cooke appeared before Wilson and motioned the court to grant a continuance in order to prepare for the contempt trial, but Wilson refused to grant a delay. ${ }^{316}$ Wilson also denied Cooke the ability to present mitigating evidence, including the fact that he had written the letter on the advice of another legal counsel. ${ }^{317}$ During the contempt proceeding, Wilson accused Walker of employing a private detective to attempt to bribe the jury foreman in his bankruptcy trial, and Wilson linked this accusation as proof that Cooke's letter was intended to be contemptuous. ${ }^{318}$ Wilson sentenced both Cooke and Walker to jail for thirty days and to pay a five hundred dollar fine. ${ }^{319}$ The U.S. Court of Appeals for the Fifth Circuit reversed Walker's conviction, but it upheld Cooke's conviction and sentence. ${ }^{320}$

Taft began the decision by observing that had Cooke merely intended to provide notice to Wilson that he did not want to file a formal affidavit, such a notice would not have constituted contempt. ${ }^{321}$ Instead, Taft determined that Cooke intended to "characterize in severe language, personally derogatory to the judge, his conduct of the pending case." ${ }^{322}$ Taft next delineated why Wilson should have recused himself

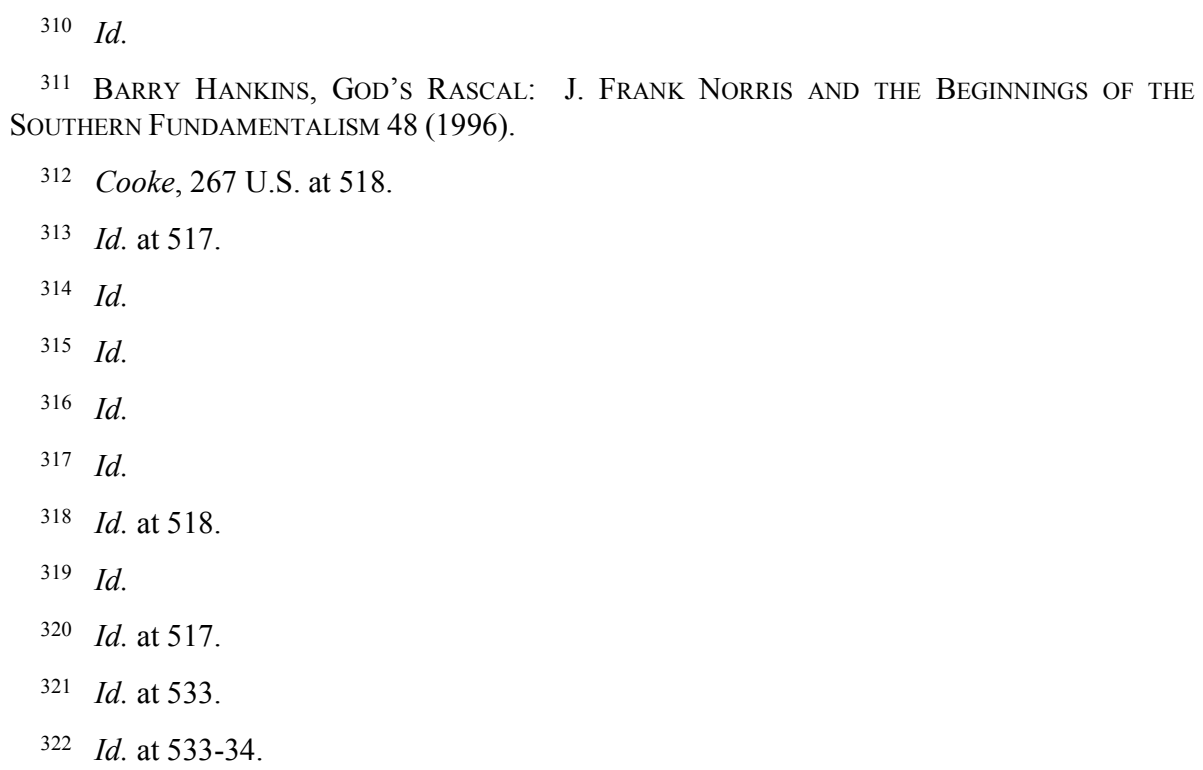


from the contempt hearing. He noted that Cooke's private conduct was not tantamount to an act in open court such as when a witness or spectator causes a disturbance, and therefore, the judge is not intended as a victim of the contempt. ${ }^{323}$ In instances where this occurs, Taft recognized that a judge must act quickly for a "summary vindication" of the "court's dignity and authority." 324 Moreover, as Taft pointed out, unlike Ex Parte Terry, in which the contempt occurred in open court, Cooke had the letter privately delivered to Wilson. ${ }^{325}$ Coupled with the fact that Wilson refused to permit Cooke and Walker time to prepare their defense and did not formally advise them of the charges, Taft determined that the contempt procedure failed due process. ${ }^{326}$ Equally important, Taft led the unanimous Court to apply the right to an impartial judge to contempt trials by strongly advising that on remand, Wilson should ask the senior judge of his district assign another judge. ${ }^{327}$

\section{IMPARTIAL JUSTICE: TUMEY V. OHIO}

Legal historian Daniel Kyvig has noted that after the Civil War, Ohio was the center of the temperance movement. ${ }^{328}$ The most powerful political organization dedicated to Prohibition, the Anti-Saloon League, originated in Cleveland in 1895. ${ }^{329}$ In one of the first challenges to the Eighteenth Amendment, Hawke v. Smith, ${ }^{330}$ the Court concluded that Ohio's method of bypassing a referendum by the voting population and reserving to the state legislature the authority to vote on the Amendment was constitutional. ${ }^{331}$ The Ohio Constitution mandated that the state's votes to amend the U.S. Constitution could only occur by a general referendum, yet the U.S. Constitution enabled Congress to determine on an amendment-byamendment basis whether the amendatory processes would occur by state legislatures or by the general votes. ${ }^{332}$ The Court easily resolved the issue by finding for the supremacy of Congress over the Ohio legislature and then applying the plain text of

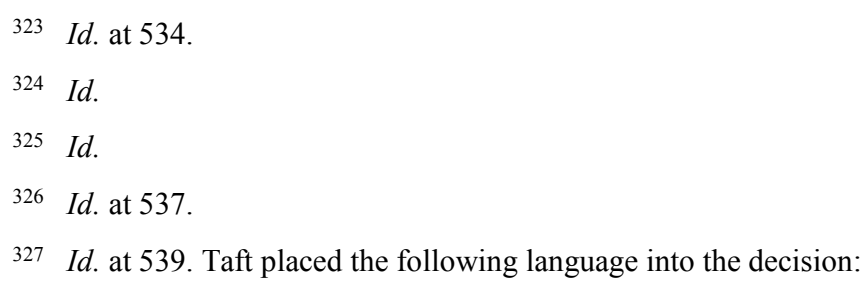

The case before us is one in which the issue between the judge and the parties had come to involve marked personal feeling that did not make for an impartial and calm judicial consideration and conclusion, as the statement of the proceedings abundantly shows.

Id. Although I do not argue this point in the text, it may be possible to apply Taft's reasoning in Cooke to a broader proposition that judicial campaign promises should serve as a definitive part of any disqualification test on challenges to a judge's service on a trial in which the promise is related to the type of cause before the court.

328 Daniel E. Kyvig, Ohio and the Shaping of the United States Constitution, in MiCHAEL Les Benedict AND John WinkLer, The History of OHIO LAw 352, 352 (2004).

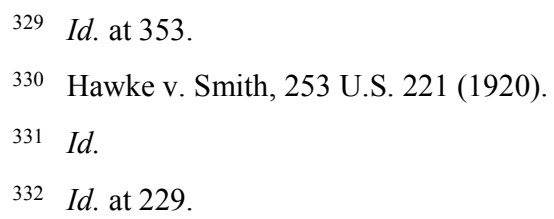


Article VI to define the term legislature as a voting body elected by a state's voting process. $^{333}$

\section{A. Tumey's Background}

Despite the Prohibition aspects to Edward Tumey's appeal, Tumey is certainly not a narrow decision on the efficacy of liquor courts or prohibition enforcement. Had the Eighteenth Amendment not come into being, an appeal involving the relationship between pecuniary interest and the right to an impartial judge might have come to the Court during Taft's tenure eventually. Early in the nation's history, state legislatures enabled the creation of inferior courts, in part, to reduce the amount of work conducted by trial judges. ${ }^{334}$ Inferior courts generally did not have the authority to convict a person of a felony, and such courts usually assessed fines rather than jail sentences. ${ }^{335}$ But some of these courts were only able to function through the collection of fines, and judicial salaries as well as police salaries were likewise contingent on the collection of fines. ${ }^{336}$

The Supreme Court generically upheld the constitutionality of inferior courts in 1917 in Hatranft v. Mullowny, Judge of the Police Court of the District of Columbia. ${ }^{337}$ In 1919, in Pacific Gas \& Electric Company v. Sacramento, the Court determined that sentences adjudged by juryless "inferior courts" did not violate the Fourteenth Amendment. ${ }^{338}$ In 1899, the city of Sacramento enacted an ordinance which required transportation companies to "sprinkle water" along track-ways to reduce airborne dust and grime. ${ }^{339}$ A local gas company operated an inter-city street railway but refused to comply with the ordinance, and the city's "inferior court" assessed a fine against the company's directors. ${ }^{340}$ The California Court of Appeals determined that the exercise of the state's "police power" was inherently constitutional and that the state legislature possessed the authority under California's Constitution to delegate this police power to municipalities. ${ }^{341}$ The Court did not take exception to the state court's analysis. ${ }^{342}$ Thus, along with the social, economic, religious, and political forces underlying Prohibition, the origins of Tumey should also be considered in light of the "police

\footnotetext{
333 See id. at 227.
}

334 See, e.g., Elizabeth Dale, Criminal Justice in the United States, 1790-1920: A Government of Laws or Men, in THE CAMBridge HISTORY OF LAW IN AMERICA 133, 153-55 (Michael Grossberg \& Christopher Tomlin eds., 2008).

335 Id.

336 Id. For a more antiquated study on this subject, but perhaps reflecting the acceptance of inferior courts, see Horace Elisha Scudder, A SHORT History of the United States 275 (1890).

337 Hartranft v. Mullowny, 247 U.S. 295 (1917).

338 Pac. Gas \& Elec. Co. v. Sacramento, 251 U.S. 22 (1919).

$339 I d$. at 23.

340 Pac. Gas \& Elec Co. v. Police Ct. of Sacramento, 28 Cal. App. 412, 413 (1915).

341 Id. at 416.

$342 I d$. at 415-16. Much of the state appellate court's decision discusses the reasonableness of the ordinance and that court noted several other state appeals court decisions upholding similar ordinances. Id. at 418-19. 
power" conferred on the states, as this power was upheld in both Hantraft and Pacific Gas and Electric. That is, Ohio's use of inferior courts as a means of enforcing both a federal and state prohibition was not per se unconstitutional.

It is also necessary to understand Ohio's inferior court construct at the time of Tumey. In the first quarter of the twentieth century, Ohio's inferior court structure could be characterized as a "hodge-podge" system of trial courts. The state's supreme court supervised not only two courts of appeal, courts of probate, and county trial courts, but also justice of the peace courts, police courts, municipal courts, and mayors' courts. ${ }^{343}$ The state was divided into eighty-eight counties containing 753 villages and 110 cities. ${ }^{344}$ Hamilton County, where Tumey lived and where North College Hill exists, had a population of 589,356 people across its 407 square miles. ${ }^{345}$ Cincinnati, the county's most populous city had a population of 541,160 , while North College Hill had a population of 4,139. ${ }^{346}$

Shortly after the Volstead Act, Ohio's legislature enacted a statute that enabled municipalities to fund prohibition enforcement through the collection of fines adjudged in juryless inferior courts. ${ }^{347}$ Ohio's law permitted the creation of municipal "liquor courts" throughout the state but not in major metropolitan centers. ${ }^{348}$ Apparently, the state legislature concluded that such "liquor courts," when placed outside of the state's major cities, created an effective cordon to prevent alcohol from entering cities where the police were unenthusiastic about enforcing Prohibition. ${ }^{349} \mathrm{In}$ 1919, North College Hill issued an ordinance that created a "liquor court." 350 The state laws and the town's ordinance enabled fines and seizures of private property to be used to fund not only the costs of the court and law enforcement, but also costs to supplement the income of judicial officers, marshals, deputies, and prosecuting attorneys. ${ }^{351}$ In various localities, including North College Hill, elected mayors served as inferior court judicial officers. ${ }^{352}$ Ohio was not, however, a state bereft of judicial ethics. The Ohio legislature had enacted a code requiring judicial recusal in cases in which a judge had a vested interest in the outcome. ${ }^{353}$ The legislature did not specifically include inferior courts or mayors serving in a judicial capacity in this

\footnotetext{
343 Paul F. Douglas, The Mayors' Courts of Hamilton County, 1-3 (1933).

344 Id.

345 Id. at 6.

346 Id. at 6.

347 Tumey v. State of Ohio, 273 U.S. 510, 517 (1927) (citing OHIO Gen. Code § 6212-37).

348 See OHIO GEN. CODE $\S$ 6212-37. "The council of any city or village may, by ordinance, authorize the use of any part of the fines collected for the violation of any law prohibiting the manufacture and sale of intoxicating liquors, for the purpose of hiring attorneys, detectives or secret service officers to secure the enforcement of such prohibition law." Id.
}

349 Tumey v. State of Ohio, 25 Ohio N.P. (n.s.) 580, 592 (1925).

350 Id. at 582.

351 Id. at 581-82.

352 Id. at 585.

353 Carey v. Ohio, 40 Ohio St. 121 (Ohio 1904) (citing Ohio Rev. StAт. § 550 (1892)). 
code. ${ }^{354}$ On the other hand, in 1917 , the Ohio Supreme Court decided that although liquor courts were "inferior courts," persons adjudged guilty in such courts had the right to appeal. ${ }^{355}$ Thus, as of 1925 , it remained an open question as to whether a liquor court judge's denial of a motion for recusal was appealable to the state trial courts or courts of appeal.

North College Hill's mayor, A.R. Pugh, also served as the town's sole liquor court magistrate and during the court's two year existence, he received over six hundred dollars from the fines assessed against defendants. ${ }^{356}$ In 1925, Pugh led an alcohol raid that resulted in law enforcement officers entering local carpenter Edward Tumey's house, where they discovered illicit alcohol. ${ }^{357}$ This raid led to Tumey's prosecution in the municipality's liquor court. ${ }^{358}$ Of the one hundred dollar fine assessed against Tumey, Pugh collected only twelve dollars. ${ }^{359}$ Tumey preserved an appeal by objecting to Pugh's service as a judge on the basis that Pugh was an interested party who had a pecuniary interest in the outcome of the trial. ${ }^{360}$ After all, if Tumey were acquitted, Pugh would receive no monies.

Tumey appealed to Judge Stanley Struble on the Court of Common Pleas, and in cutting language, Struble reversed Tumey's conviction and fine. ${ }^{361}$ A 1988 biographical article described Stuble as "a teetotaler but not a prohibitionist" and went on to note that Tumey was a local carpenter and not a notorious bootlegger. ${ }^{362}$ The author of the biographical article also reported that Struble was angry with law enforcement officials for arresting and prosecuting working citizens instead of focusing on well-known gangsters. ${ }^{363}$ Another character aspect of Struble is that he

\footnotetext{
354 See generally OHIO REV. STAT. § 550.

355 Heninger v. Davis, 96 Ohio St. 205 (1917).
}

356 Tumey, 25 Ohio N.P. (n.s.) at 583. According to Judge Struble, in 1925, Pugh ran for office with the promise to vigorously enforce the Crabbe Act and maximize the use of the municipality's liquor court. Id. Struble's characterization is particularly apt, as follows:

It was admitted that Mayor Pugh was at the time, a taxpayer in the village of North College Hill, and at the time of the resignation of Mayor Vogelpohl, his predecessor, on account of his disinclination to operate a liquor court, in the public agitation that followed Vogelpohl's resignation as to whether or not the court should be continued as an enterprise of the village, Mayor Pugh in public speeches advocated the continuance of this liquor court because of the "financial" benefit to the village. Mayor Pugh was appointed as the successor of Mayor Vogelpohl.

Id.

357 Eric T. Kasper, Impartial Justice: The Real Supreme Court Cases that Define the Constitutional Right to a Neutral AND Detached Decision-MAKer 81-82 (2013).

358 Id. at 83.

359 Id. at 84.

360 Tumey, 25 Ohio N.P. (n.s.) at 583.

361 Tumey v. State of Ohio, 273 U.S. 510, 515 (1927).

362 Jerry Hurter, The Way We Were: Don Quixote Judge and Cause Celebre, Kangaroo Court Tyranny K.O. 'd Sixty-One Years Ago, Cincinnati MAG., Mar. 1988, at 43.

363 Id; see also CINCINNATI ENQUIRER, supra note 6; Stanley Struble Dies Near 90th Birthday; Famed as Judge of Plain Common Sense, CincinNATi EnQuirer, Feb. 4, 1955, at 40. 
appears to have been popular with southern Ohio's ethnic German population for defending the teaching of the German language during World War I. ${ }^{364}$ One could conclude that Struble was concerned about the due process rights of minorities and individual citizens against Ohio's assertion of its "police power."

Struble determined that because Pugh and others benefited from convictions, Tumey was deprived of the right to due process of law. ${ }^{365}$ Midway through the decision, he penned:

The power and authority given of making of mayors of villages special instruments in the enforcement of prohibition was bad enough, but considering this in connection with what has been done in other ways for prohibition enforcement, we are forced to conclude that we have a situation that seriously menaces the liberties of the people. ${ }^{366}$

Although his disgust with the state's prohibition enforcement scheme appeared throughout the decision, Struble carefully analyzed due process in light of not only state constitutional law, but also the common law predating the Constitution. ${ }^{367}$ Pugh had argued that because a liquor court could not assess a sentence of imprisonment, it was a lesser court, immune from the requirement of a jury trial and, therefore, the rules governing recusal did not apply. ${ }^{368}$ Struble countered that persons who were unable to pay a fine would be placed in prison to work off the fine at a rate of sixty cents per day, and a person could be confined for nine years after being found guilty of a second offense. ${ }^{369}$ Struble cited to Schick $v$. United States ${ }^{370}$ for the proposition that because violations of both the Volstead Act and Ohio's prohibition laws were rooted in the Eighteenth Amendment, Tumey's offenses were of a constitutional magnitude and, therefore, could not be considered as a petty offense akin to public swearing. ${ }^{371}$

Struble next discounted Pugh's argument that because the Ohio legislature had exempted mayors in the judicial ethics statutes by omission, Pugh was free to ignore Tumey's objection to his service as a judicial officer. ${ }^{372}$ Because the state constitution listed a series of inalienable rights, including the right to seek redress in the courts, Struble found that Pugh had an obligation to at least consider whether he had a duty

This article is an obituary in which Hamilton County's municipal judges recalled Struble, who had reached the age of ninety. The obituary states, "His passing, the courts and the bar have lost a judge whose fairness and courage have brought national recognition to the bench of Hamilton County, and the people of this community have lost an outstanding citizen." Id.

364 Letter from H. L. Lebkuecher, H. L. Lebkuecher Cigars, to William Howard Taft, Chief Justice, U.S. Supreme Court (March 11, 1927) (on file in the Library of Congress).

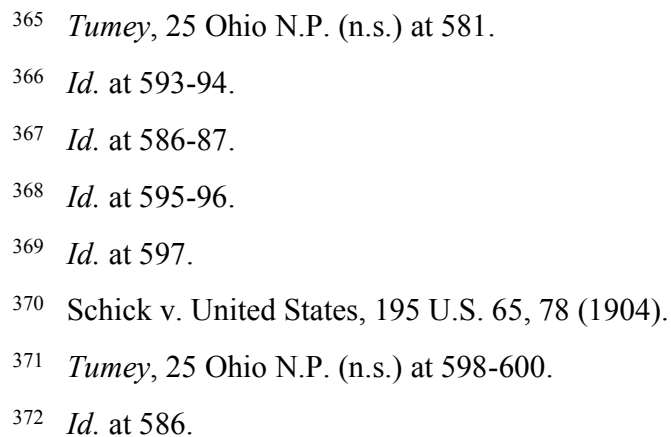


to disqualify himself in light of Tumey's due process rights but had not done so. ${ }^{373}$ Pugh relied on an 1881 Ohio Supreme Court decision which had determined that the term "pecuniary interest" did not include a dependency on "court cost" to supplement income. ${ }^{374} \mathrm{He}$ argued that his collection of a share of the assessed fines was not, alone, a basis for mandatory recusal. ${ }^{375}$ Struble distinguished Tumey's appeal from the 1881 decision because Pugh had collected for his own use a greater amount of money than simply the costs of running the court. ${ }^{376}$ Ohio's First District Court of Appeal reversed Judge Struble's ruling with little comment, and the Ohio Supreme Court refused to grant Tumey a further appeal. ${ }^{377}$

Then, Tumey appealed for a writ of certiorari to the U.S. Supreme Court, and Taft convinced the other eight justices that the appeal was of a constitutional magnitude. ${ }^{378}$ Although Taft did not, in any of his surviving correspondences, discuss his view of a judicial system that relied on mayors or justices of the peace to conduct criminal trials, in his 1916 Kentucky Law Review article, he had disparaged the system of lesser courts and observed that such courts were weighted against the rights of the nation's poor. ${ }^{379}$ Perhaps presaging the Court's grant of certiorari to Tumey's appeal, Taft insisted that the best means to achieve a fair and equitable system of lesser courts was to ensure that the Supreme Court had the jurisdictional authority to take appeals from the decisions of such courts. ${ }^{380}$

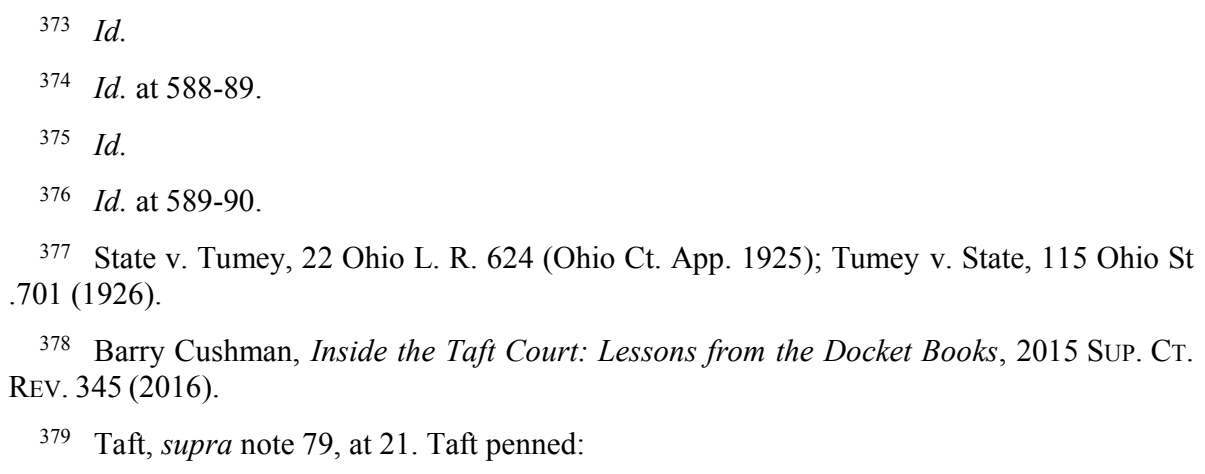

378 Barry Cushman, Inside the Taft Court: Lessons from the Docket Books, 2015 SUP. CT. Rev. 345 (2016).

379 Taft, supra note 79 , at 21 . Taft penned:

We have had through the country a system of civil courts conducted by men who are not lawyers, by justices of the peace, with appeals from the justice's court to the common pleas court, or superior court of first instance, and then with appeals through intermediate courts of appeal to the Supreme Court. If a system could be devised that offered greater advantage to the wealthy litigant in resisting the claims of the poor litigant, I don't know what it is.

Id.

\section{Id. Taft urged that}

[t]he justices of the peace generally have very little knowledge of the law, are not men of skill and learning, able to dispose of business promptly and accurately, and so the cases too frequently drag along in the so-called "people's courts" until the poor litigant is discouraged and really defeated, even when he wins in a court of last resort. The poorer people are entitled to as good judges as the rich, and they cannot get them by giving them an appeal to the highest court in their cases, because that involves such delay and expense. The cutting off appeals from the people's courts to the Supreme Court is one means of preventing that inequality between the poor and the rich litigant that now prevails. 


\section{B. Tumey v. Ohio: The Decision}

On appeal to the Court, some of the nation's most powerful prohibition advocates represented the state of Ohio. The team included Attorney General Charles C. Crabbe, Wayne Bidwell Wheeler, Edward B. Dunford, D. W. Murphy, and Charles M. Earhart. ${ }^{381}$ Wheeler was the president of the Anti-Saloon League, a national organization with chapters in all forty-eight states, and he was instrumental in forming a powerful congressional alliance to enable the Volstead Act. ${ }^{382}$ In 1922, Senator John Shields, a Tennessee Democrat, accused Wheeler of supporting Taft's efforts to empower the Supreme Court to temporarily assign district court judges to other districts when vacancies occurred or when district caseloads became untenable for a hidden purpose of bringing "avowed dry judges into wet territory." 383 This accusation was the opposite the Anti-Saloon League's accusations against Taft. Dunford was the national Anti-Saloon League's vice president. ${ }^{384}$ Earhart was the president of the Ohio Anti-Saloon League. ${ }^{385}$ And, Murphy was a state prosecutor who had campaigned for the Eighteenth Amendment. ${ }^{386}$ There is a historic consensus that Wheeler was instrumental in the election defeats of Senators Atlee Pomerene of Ohio and Owlsey Stanley of Kentucky in 1922..$^{387}$

Crabbe's representation of Ohio is explained by his duties as Attorney General and that Ohio did not yet have a state solicitor general. Wheeler and the other prohibitionists, however, are a different matter. Historian Daniel Okrent, in his Last Call: The Rise and Fall of Prohibition, described Wheeler as a powerful political force who was instrumental in the Eighteenth Amendment's passage and who was also a force in reshaping the Ohio legislature. ${ }^{388} \mathrm{He}$ represented the Ohio legislature in Hawke v. Smith and advocated in other prohibition suits before the Court. ${ }^{389}$ Wheeler

Id.

381 However, the names of the state's attorneys are note listed on the decision. See ClEMENT E. Vose, Constitutional Change: Amendment Politics and Supreme Court Litigation SINCE 190097 (1972).

382 OKRENT, supra note 108, at 39.

383 MASON, supra note 266, at 101.

384 Sigma Phi Epsilon, The Sigma Phi Epsilon Journal 232 (1921).

385 The Phi Delta Theta Fraternity, The Scroll of Phi Delta Theta, Vol. XXXIV 417 (1910).

386 The Railroad COMmission of OHIO, Report to the RaILroad COMmission OF OHIO TO THE GOVERNOR 70 (1911).

387 OKRENT, supra note 108, at 229.

388 Id. at 39.

389 Wheeler also filed an amicus brief in Lambert v. Yellowly, 272 U.S. 581 (1926), a decision in which the Court determined that Congress had the power to prohibit the use of alcohol in prescription medicines, Cunard v. Mellon, 262 U.S. 100 (1923), which determined that Congress had the authority to extend the Eighteenth Amendment's prohibitions to foreign vessels using United States ports, and, The National Prohibition Cases, 253 U.S. 350 (1920). 
and Taft had known each other for at least five years before Tumey. ${ }^{390}$ In 1922 , Wheeler led the Anti-Saloon League to openly support Taft's efforts to increase the number of district court judges after its leaders had initially opposed Taft's plan. ${ }^{391}$ In 1923, Taft lauded Wheeler to his brother Horace in writing, "Wheeler is a man of real power and great common sense." ${ }^{392}$ One year later, Attorney General Harlan Fiske Stone inquired to Taft about whether Roscoe J. Mauck, an Ohio judge on the state court of common pleas, was a reasonable candidate to be nominated for a federal judgeship. ${ }^{393}$ Mauck, unfortunately, had appeared drunk in public prior to the Eighteenth Amendment, but the Anti-Saloon League had later lauded his decisions in upholding the Crabbe Act, and he did not oppose prohibition measures during the state Republican Convention in 1924. ${ }^{394}$ Taft replied to Stone that he had sought out Wheeler's opinion to determine whether the Anti-Saloon League would oppose Mauck and that Wheeler conveyed back to him "that while at the state convention [Mauck] had kept straight, he was very much afraid that given the independence of a position on the Federal Bench in the larger cities, Mauck might yield again, to liquor." ${ }^{395}$ In January 1926, Wheeler felt comfortable enough to ask Taft to lobby the justices against narrowing Ohio's conspiracy laws in a pending appeal unrelated to Tumey's. ${ }^{396}$

By late 1926, Taft's view of Wheeler appears to have changed. In November, shortly after the parties submitted their initial briefs to the Court but before argument, the Anti-Saloon League published an article about the Chief Justice which claimed that he had opposed exempting beer and light wines from the Eighteenth Amendment "because it would leave a hole through which a coach and four could be driven and the effectiveness of the law destroyed." ${ }^{397}$ Taft, in fact, had given a newspaper

390 Letter from Wayne Wheeler, President, Anti-Saloon League, to William Howard Taft, Chief Justice, U.S. Supreme Court (Aug. 26, 1922) (on file in the Library of Congress).

391 Id.

392 Letter from William Howard Taft, Chief Justice, U.S. Supreme Court, to Horace D. Taft, brother of William Howard Taft (Nov. 11, 1923) (on file in the Library of Congress). The remainder of Taft's comment regarding Wheeler is:

He is miles away from the pestiferous Anderson, the head of the Anti-Saloon League in New York, who has brought much discredit on the movement. I do not doubt Wheeler sees the great advantage of using the Civil Service Commission to get good men into the prohibition department, but I presume that in order to hold his position among Congressmen he has found it necessary not to be active in that particular direction, because his activity would be a sin against the Holy Ghost, with the ordinary congressman and senator.

Id.

393 Letter from William Howard Taft, Chief Justice, U.S. Supreme Court, to Harlan F. Stone, Attorney General (Dec. 7, 1924) (on file in the Library of Congress).

394 Id.

395 Id.

396 Letter from Wayne B. Wheeler, President, Anti-Saloon League, to William Howard Taft, Chief Justice, U.S. Supreme Court (Jan. 26, 1926) (on file in the Library of Congress).

397 Letter from William Howard Taft, Chief Justice, U.S. Supreme Court, to Horace D. Taft, brother of William H. Taft (Nov. 12, 1926) (on file in the Library of Congress). 
interview in late 1918, while serving as a Yale law professor, in which he had made this comment, but he had done so for purposes other than supporting a stricter prohibition amendment. ${ }^{398}$ Taft instead argued that the law had to be entirely prohibitory or not exist at all, because exceptions for beer and "light" wines would make the amendment unenforceable. ${ }^{399}$ Taft complained to his brother Horace, "One of the features of the fight over prohibitionists and anti-prohibition is the utter unscrupulousness of both sides in the use of evidence." 400 Wheeler attempted to assure Taft that he had nothing to do with the Anti-Saloon League's article and wrote the chief justice a formal apology. 401

On March 6, 1927, when Taft wrote to his son Charles that the Crabbe Act was unconstitutional, he also noted that the decision "necessitated an examination of English and American law" and was disappointed in both Wheeler and Tumey's counsel, Edward Moulinier. ${ }^{402} \mathrm{He}$ further wrote, "The truth is that the case was not fully prepared on either side. We required them to go back and file new briefs, and after that, we found that there was a great deal of work to be done by the Court." 403 What Taft did not mention is that Wheeler and Mouliner were both late on their briefs, and they filed a total of four apiece. ${ }^{404}$ Wheeler argued to the Court that because the Fourteenth Amendment did not require trials by jury, state legislatures were free to create courts as deemed necessary. ${ }^{405}$ Wheeler added that because several states, since the beginning of the nation, had permitted judges to keep adjudged fines as part of their salary, due process did not prohibit this practice. ${ }^{406}$ The state's third and final argument was that the fine collected from Tumey was miniscule and, therefore, not worthy of the Court's time. ${ }^{407}$

Taft began the decision by narrowly fashioning the question before the Court. The Court addressed the narrow issue of whether Ohio's scheme of permitting a mayor to serve in a judicial position in which the mayor possessed a pecuniary interest in the outcome of the trial failed due process under the Fourteenth Amendment. ${ }^{408}$ Following

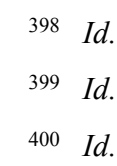

401 Letter from Wayne B. Wheeler, President, Anti-Saloon League, to William Howard Taft, Chief Justice, U.S. Supreme Court (Nov. 12, 1926) (on file in the Library of Congress); Letter from William Howard Taft, Chief Justice, U.S. Supreme Court, to Wayne B. Wheeler, President, Anti-Saloon League (Nov. 13, 1926) (on file in the Library of Congress).

402 Letter from William Howard Taft, Chief Justice, U.S. Supreme Court, to Charles P. Taft, son of William H. Taft (Mar. 6, 1927) (on file in the Library of Congress).

403 Id. Little is known about Edward Moulinier. He was a local Ohio attorney who fought against the Crabbe Act. See Edward Moulinier, Fought Prohibition, N.Y. TIMES, Mar. 2, 1951, at 92 .

404 Wayne B. Wheeler, President, Anti-Saloon League, to William Howard Taft, Chief Justice, U.S. Supreme Court (Dec. 18, 1926) (on file in the Library of Congress).

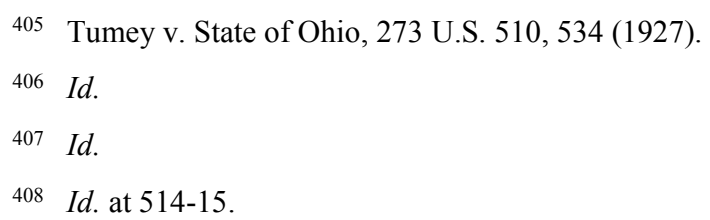


this question, he detailed the various Ohio statutes and municipal ordinances that created the North College Hill court. Then, he went on to note that between May 11, 1923, and December 31, 1923, the town court collected over \$20,000, of which Mayor Pugh received $\$ 696.35 .{ }^{409}$ The county marshals, inspectors, detectives, and other city and county employees received $\$ 2,697.75$ while a prosecutor received $\$ 1,769.50 .{ }^{410}$ Had the hundreds of trials resulted in acquittals rather than convictions, none of this money would have been available to pay the various officials involved in the enforcement of Prohibition. ${ }^{411}$ Taft also recognized that prior to Tumey's trial, Pugh had made public statements which could be construed in favor of maintaining the liquor court. ${ }^{412}$

Next, Taft articulated a basic rule that judicial officers and persons acting in a judicial capacity must be disqualified from adjudicating a controversy in which they have a pecuniary interest. ${ }^{413} \mathrm{He}$ cited to no federal judicial precedent for this principle, but rather he turned to several state judicial decisions, all of which arose from civil matters such as land use, probate, and debt collection. Two of these decisions originated from railroad interests in private property. One case Taft highlighted was a Michigan appellate decision in which jurors empaneled on a judgeless probate court voted to assign an intestate decedent's land for railroad use, but the jurors were shareholders in the railroad and stood to benefit from the assignment; therefore, the trial failed due process. ${ }^{414}$ The second decision Taft highlighted, and in his opinion, the most important because it arose in Ohio, was Gregory v. Cleveland, Columbus, \& Cincinnati Railroad Company. ${ }^{415}$ In 1855, the Ohio Supreme Court upheld a lower court's determination that commissioners appointed to assess a property owner's loss of property resulting from a taking of land for the purpose of railroad track construction could not have a pecuniary interest in the railroad company. ${ }^{416}$ Specifically, two of the commissioners were stockholders in the defendant railroad

\footnotetext{
409 Id. at 516-22.

410 Id.

411 Id.

412 Id. at 521.

413 Id.

414 Id. (citing Peninsular Country R.R. v. Howard, 20 Mich. 18 (1870). In this decision, the Michigan Supreme Court noted:
}

The maxim that no man shall be judge in his own cause, is one deeply rooted in the common law, and can never be overlooked anywhere, where impartial justice is one of the objects of judicial administration. And in this special proceeding for taking the property of individuals against their will, in which the jury act in effect as judges, in the absence and beyond the control of the Court, we think this maxim is applicable to them as well as judges.

Id. at 25 .

415 Gregory v. Cleveland, Columbus, \& Cincinnati R.R. Co., 4 Ohio St. 675 (1855).

416 Id. at 677. 
company; therefore, they had a motive to undervalue the loss of property. ${ }^{417}$ The state justices stated, "No man should be the judge in his own cause." 418

It might appear, at first glance, that Taft wanted the decision to be applied narrowly to only financial issues because, after noting the state decisions involving the necessity of judicial disqualification in matters of a pecuniary nature, he pointed out that not all questions of judicial disqualification involved "constitutional validity." ${ }^{19}$ In contrast to financial questions, Taft concluded, "[M] atters of kinship, personal bias, state policy, remoteness of interest, would seem generally to be matters merely of legislative discretion." ${ }^{420}$ To this end, Taft cited to Wheeling v. Black, ${ }^{421}$ a West Virginia decision in which that state's supreme court determined that the state legislature had the authority to enact a statute to prevent judicial officers from being disqualified on the basis of also being tax-payers. ${ }^{422}$ In Wheeling, a West Virginia municipality sued a former tax collector after claiming that the collector had wrongfully withheld tax payments from the municipality and kept the monies for his own enrichment. ${ }^{423}$ The trial judge was a taxpayer to the municipality, and his salary derived from the collection of taxes. ${ }^{424}$ The state supreme court did not consider the municipality's appeal on the basis of due process; rather, the court considered whether the state legislature had the lawful authority to enact an anti-disqualification statute. ${ }^{425}$ Moreover, very little of the state supreme court's decision focused on recusal; instead, the state court spent much of the decision considering the collector's evidentiary objections as well as a petition for a change in forum. ${ }^{426}$

\footnotetext{
417 Id.

$418 I d$. at 677 . The state court went on to note:
}

We think, for the administration of justice, the safe way is, in all cases, for interested judges to decline acting in such cases; and where it appears, on the record, that they were interested, and acted on questions of fact, and especially when they were to select the jury who try the facts, they should refuse to sit, and make known their interest at the earliest stage of the proceedings.

Id. at 679 .

419 Tumey v. Ohio, 273 U.S. 510, 523 (1927).

420 Id.

421 Wheeling v. Black, 25 W. Va. 266, 270 (1884).

422 Id. at 279. The statute read:

No judge of any court, and no sheriff or other officer of a court, shall be disqualified from performing his official duties with respect to any cause by reason of the fact that he is a citizen and tax-payer of a county, district, school district, or municipal corporation which is interested in, or a party to such cause.

W. VA. CODE $§ 51-3-6$ (1881).

423 Wheeling, $25 \mathrm{~W}$. Va. at 270.

${ }^{424}$ Id. at 280.

425 Id. at 282.

426 See generallyid. 
Prior to Tumey, the nation's state and federal courts had not issued a dispositive decision on the nexus between kinship and recusal. In terms of family relationships or personal bias, Taft believed that either state legislatures or the judicial profession itself were the proper instruments for regulating judicial conduct in matters of kinship. ${ }^{427}$ Taft was concerned with appearances, but he also did not want to criticize the past practices of the Supreme Court. In 1933, Justice Van Devanter informed Chief Justice Charles Evans Hughes that in Tumey, Taft approached kinship in a cautious manner because he did not want to impugn the legacies of other justices. ${ }^{428}$ According to Van Devanter, Taft explained that during and after the Civil War, noted attorney David Dudley Field argued appeals to the Court while his brother Stephen Field was a justice. ${ }^{429}$ Justice Field was, in fact, particularly concerned about his judicial service during Lambdin Milligan's appeal because his brother David argued Milligan's appeal to the Court. ${ }^{40}$ Apparently, Taft had personal reasons for believing that, although there was an appearance of impropriety in Justice Field's service on appeals where his brother argued, it was appropriate to permit the state courts and legislatures to develop rules regarding recusal and disqualification. ${ }^{431}$

After disposing of questions regarding kinship, personal bias, state policy, or remoteness of interest, Taft turned to ancient rules involving the need for an impartial judiciary as related to pecuniary interests. He did so as a response to Ohio's assertion that in order to determine the parameters of due process under the Fourteenth Amendment, the Court had to:

[L]ook to those settled usages and modes of proceedings existing in the common and statute law of England before the emigration of our ancestors, which were shown not to have been unsuited to their civil and political condition by having acted on them after the settlement of this country. ${ }^{432}$

427 Tumey v. Ohio, 273 U.S. 510, 523 (1927).

428 Letter from Willis Van Devanter, Assoc. Justice, U.S. Supreme Court, to Charles Evans Hughes, Chief Justice, U.S. Supreme Court (Oct. 7, 1935) (on file in the Library of Congress).

429 Id.

430 Letter from Justice Stephen J. Field to Chief Justice Salmon P. Chase (June 30, 1866), in The SAlmon Chase PAPers, Vol. V, 115-17 (John Niven et al. eds., 1998). Ironically, perhaps, is the example set not only by Justice Field and merely touched upon by Chief Justice Taft that would later prove vexatious to the Supreme Court. For instance, future Justice Abe Fortas provided legal advice to Justice William O. Douglas including negotiating a book contract for Douglas in 1947, but Douglas did not recuse himself from cases in which Fortas argued. See Laura Kalman, Abe Fortas: A Biography 164-65 (Yale Univ. Press ed., 1990). Although Professor Kalman did not address Tumey in her study on Fortas, she noted that by the midtwentieth century relationships between judges and litigants had evolved into a public issue. See $i d$. In 1946 Justice Jackson publicly criticized Justice Hugo Black for participating in a case where Black's former law partner from over two decades earlier represented a party. See, e.g., William Wiecek, History of the Supreme Court of the United States: THe Birth of the Modern Constitution: The United States Supreme Court, 1941-1953, Vol. XII, 414-16 (Stanley N. Katz ed., 2006).

431 See infra note 433.

432 Tumey, 273 U.S. at 523. The Ohio solicitor general's brief cited to Ownbey v. Morgan, 256 U.S. 94 (1921), a property attachment and seizure decision and Murray's Lessee v. Hoboken Land \& Improvement Co., 59 U.S. 272 (1855), a land ejectment decision. Neither of 
Taft noted that during the reign of Richard II, justices of the peace were paid for their services out of common sheriffs' funds, and the payment was a flat rate regardless of whether the justices of the peace convicted or acquitted a person. ${ }^{433}$ Although parties to a lawsuit in medieval England were subject to the rule of "amercement pro falso clamore," a term denoting that the losing party had to pay the costs of a lawsuit, judges and other judicial officers were not paid on the basis of their decisions. ${ }^{434} \mathrm{Taft}$ summarized the importance of this practice: "There was at the common law the greatest sensitiveness over the existence of any pecuniary interest however small or infinitesimal in the justices of the peace." 435 Read in its context and given Taft's conservatism, it appears that Taft found it important that the laws confining English justices of the peace to salaries remained the law of England. ${ }^{436}$

Taft lamented that Ohio, Arkansas, Kentucky, Nebraska, North Carolina, Maryland, Georgia, and Texas had disregarded the English standard and permitted "inferior" judicial officers' salaries to be paid from the collection of fines. ${ }^{437}$ However, judicial officer salaries in Maryland were "fixed," and while contingent on the collection of fines, a judge did not increase his or her salary by the numbers of convictions. ${ }^{438}$ Both Texas' and Georgia's highest appeals courts had upheld the basic construct of permitting fines to be used for judicial officer salaries. ${ }^{439}$ In Bennett $v$. State, the Texas Court of Appeals, in a very brief decision arising from a defendant's challenge against a misdemeanor judge, simply held that the Texas legislature had

these two decisions arose from an appeal challenging the competency of a judicial officer to determine a cause of action.

433 Id. at 521. Taft may have oversimplified his reliance on British legal history regarding judicial salaries. English judges could also collect fees from parties for their service as adjudicators though such fees were paid regardless of the judicial decision. Also, because judicial salaries often went unpaid, it was not unusual for judges to receive land grants and pensions from large landholding aristocrats. See, e.g., William SEARLE HoldSwORTH ET AL., A History OF ENGLiSH LAW, VOL. I 252-54 (Nabu Press ed., 1922).

434 For a history of this rule in the United States, see Lowe v. Kansas, 163 U.S. 81 (1986) (discussing that Kansas law allows for prosecutors who engaged in malicious prosecution to be subject to court costs after a specific finding of such by a jury upheld); Day v. Woodworth, 54 U.S. 563 (1852) (finding it constitutional that a plaintiff may be responsible for court costs); John D. Lawson, The Action for the Malicious Prosecution of a Civil Suit, 30 Am. L. REg. 281, 364 (1882). See generally Robert W. Taylor, Restraints on Vexatious Litigation, L. MAG. \& REV. 670, 676 (1875).

435 Tumey, 273 U.S. at 523. Scholars who analyzed Caperton have overlooked Taft's belief that common law barred the judicial conduct at issue in Tumey. See, e.g., Andrey Spektor \& Michael Zuckerman, Judicial Recusal and Expanding Notions of Due Process, 13 U. PA. J. CONST. L. 977, 986 (2011).

436 Tumey, 273 U.S. at 521.

437 Id. at 526.

438 Id. at 527 (citing Herbert v. Baltimore County Comm'r, 55 A. 376 (Md. 1903); In re Application of J.D. Guerrero, 10 P. 261 (Cal. 1886)).

439 See generally Wellmaker v. Terrell, 3 Ga. App. 791 (1908); Bennett v. State, 4 Tex. Ct. App. 72 (1878). 
mandated that the payment of judicial salaries was contingent on convictions. ${ }^{440}$ The defendant had been convicted of operating a betting parlor, and the judge fined him fifty dollars. ${ }^{441}$ The Texas court did not provide any due process analysis as to the statute and, instead, focused on the judge's adherence to a statute rather than whether the statute was unconstitutional. ${ }^{442}$

In Wellmaker v. Terrell, the Court of Appeals of Georgia, in a lengthier analysis, concluded that the payment of fees collected from parties in lieu of fixed judicial salaries was not unconstitutional. ${ }^{443}$ The city of Barnseville, in conformance with Georgia law, established an inferior court, and the judge assigned to the court also served as a judicial clerk. ${ }^{444}$ Wellmaker had paid a bond to the court for the release of a citizen accused of larceny while the citizen awaited trial. ${ }^{445}$ The citizen fled from the district, and Wellmaker forfeited the bond money. ${ }^{446}$ He appealed the forfeit on the basis that because the inferior court judge would only be paid if the citizen had been convicted; the court possessed no jurisdiction over the bond. ${ }^{447}$ Unlike Texas, Georgia law prohibited a judge from adjudicating a cause of action in which he had a pecuniary interest. ${ }^{448}$ However, the state court of appeals determined that judicial payments based on fines collected did not fall within the ambit of "pecuniary interest." 449 Also, the Georgia court, like its Texas counterpart, deferred to the legislature noting:

As we cannot conclude that the General Assembly of 1899 intended not to create the court, which it solemnly declared it was creating, as well as on account of the other reasons to which we have referred, we are constrained to hold that the judge of the city court was not disqualified to preside in the case now before us. ${ }^{450}$

Taft approvingly noted that the California, Florida, Louisiana, and South Carolina state constitutions prohibited judicial officers serving in minor courts to be paid from the collection of fines and mandated judicial salaries from the state, regardless of whether defendants were convicted or acquitted. ${ }^{451}$ However, Taft returned to the question of the application of common law to the issue of impartiality, and this resulted in the somewhat disjointed nature of the decision. ${ }^{452} \mathrm{He}$ pointed to several state

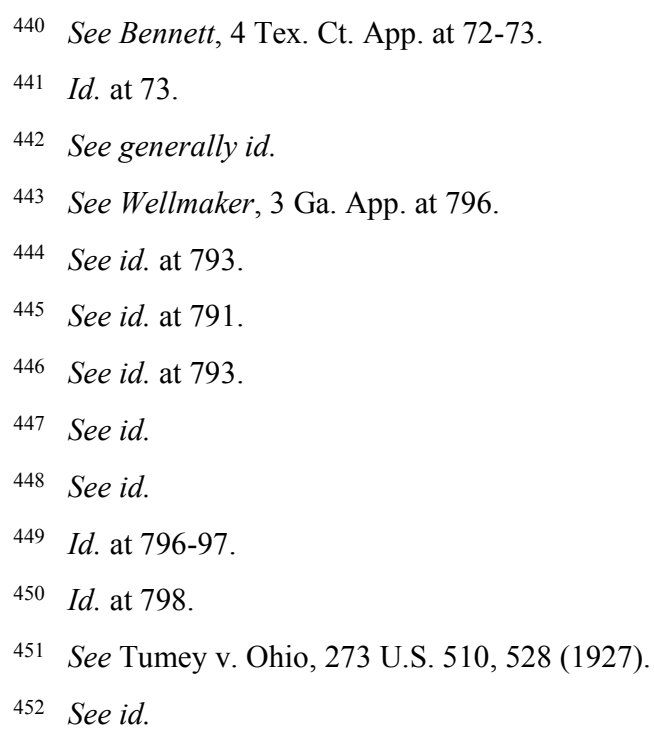


decisions in which citizens who happened to be taxpayers were deemed to be incompetent to serve as jurors in a suit involving the municipality in which they resided. ${ }^{453}$ On the other hand, he accepted that a taxpayer interest could be considered remote to the point of not requiring disqualification. ${ }^{454}$ To Taft, the issue of juror competency served as an important analog to the status of inferior judges because inferior judges served as a trier of fact. From this analysis, he concluded that Ohio's argument that the common law permitted inferior judges to collect fines as a salary had no basis. ${ }^{455}$ Taft quickly dispatched the state's final argument that Tumey had been fined the minimum amount permissible under law after being adjudged guilty by the overwhelming weight of the evidence. Taft responded to this argument by noting that a party's right to an impartial judge was more important. ${ }^{456}$ In other words, the amount of the fine was not pertinent to right to an impartial judge.

\section{Kinship: The Taft Family}

The decision's "kinship" statement is noteworthy beyond Van Devanter's recollection of Taft's reasoning to Chief Justice Hughes. In 1925, the voters of Hamilton County, Ohio elected Taft's son, Charles Phelps Taft II, as their county prosecutor. ${ }^{457}$ The younger Taft had promised the county's electorate that he would vigorously prosecute bootleggers and violent criminals, and Taft was intensely proud of his son. ${ }^{458}$ In August of that year, Taft wrote to Justice Sutherland, "My younger boy, Charles P Taft, 2d has just been nominated for Prosecuting Attorney of Hamilton County, where Cincinnati is. This is a very important position and one which offers an opportunity that is quite unusual at his age of twenty-nine." ${ }^{\circ 59}$ Taft described his son's campaign: "He was at the head of the citizens' organization in the primary against the regular organization. They had an election at which there were 60,000 votes, and it was hotly contested. Charlie won by 1,000 votes. [It was close so there had to be a recount]." 460

From the end of 1925 through the Court's issuance of the decision, Taft maintained an ongoing correspondence with his son about prohibition enforcement. Contained within their letters is the fact that Judge Struble had sworn Charles into practice as a prosecutor in late November 1925 and that Taft wrote a letter to Struble not only thanking the judge for his kind words for his son, but also lauding Struble for his

453 Id. at 529 (citing Divieny v. City of Elmira, 51 N.Y. 506 (1873); Corwein v. Hames, 11 Johns 76 (N.Y. Sup. Ct. 1814); Fine v. St. Louis Pub. Sch., 30 Mo. 166 (1860); In re New Boston, 49 N.H. 328 (1870)).

454 See Tumey, 273 U.S. at 531.

455 Id. at 535.

456 Id.

457 Stephen Hess, America's Political Dynasties: From Adams to Clinton 332-33 (Brookings Inst. ed. 2016).

458 Id.

459 Letter from William Howard Taft, Chief Justice, U.S. Supreme Court, to George Sutherland, Assoc. Justice, U.S. Supreme Court (Aug. 25, 1926) (on file in the Library of Congress).

460 Id. 
decision in Tumey's appeal. ${ }^{461}$ Taft's letters to Struble cannot be found in either his very large collection or that of his son, and Struble did not leave any historic repository of his papers. But, on January 4, 1927, Charles wrote to his father:

I just have time to enclose a copy of remarks Judge Struble made at my swearing in ceremony, although I did not expect him to say anything in particular. I think he would appreciate a letter from you and I should like to have you return this copy to me when you have read it. ${ }^{462}$

Taft, in turn responded to Charles two days later, "I am returning herewith the stenographic copy of the remarks of Judge Struble at your induction in office. The judge was very kindly in the language he used. I shall be glad to write him a letter and say so." 463 On January 17, Charles informed his father that Struble "was tremendously pleased and has been showing it to everybody." 464

On March 12, 1927, Charles informed his father that the Supreme Court's decision was widely lauded throughout the state. ${ }^{465}$ Charles wrote, "You may have had the idea before this that you were popular in your own state, but if you did not, you need now revise your ideas." ${ }^{466}$ Charles further praised his father, "I think that statues of you will probably be erected in every city in Ohio. In fact, your glory is being reflected in the name of Taft no matter who bears it, and I feel that if you were to run again now for any office, it would secure a two-third majority." 467 In spite of this exchange, Tumey should not be considered as evidence that Taft believed there were too many prosecutions or that the problem of crime was overstated.

Both the Chief Justice and his son believed that there were significant increases in crime not only in Hamilton County or Ohio, but also in the nation at large. In August 1927, Taft wrote to Charles that he was concerned with the "Cincinnati crime wave" and understood that the failure to stop bootlegging, prostitution, and murder would cripple confidence in the government. ${ }^{468}$ Taft noted to his son, "The immunity of these bootleggers, due to the original conspiracy which prevents and terrorizes the natural witnesses of the crime, is something I presume they have had in other parts of the country." ${ }^{469}$ He further mentioned:

461 Id.

462 Letter from Charles P. Taft, son of William Howard Taft, to William Howard Taft, Chief Justice, U.S. Supreme Court (Jan. 4, 1927) (on file in the Library of Congress).

463 Letter from William Howard Taft, Chief Justice, U.S. Supreme Court, to Charles P. Taft, son of William Howard Taft (Jan 9, 1927) (on file in the Library of Congress).

464 Letter from Charles P. Taft, son of William Howard Taft, to William Howard Taft, Chief Justice, U.S. Supreme Court (Jan. 17, 1927) (on file in the Library of Congress).

465 See letter from Charles P. Taft, son of William Howard Taft, to William Howard Taft, Chief Justice, U.S. Supreme Court (Mar. 12, 1927) (on file at the Library of Congress).

466 Id.

467 Id.

468 Letter from William Howard Taft, Chief Justice, U.S. Supreme Court, to Charles P. Taft, son of William Howard Taft (Aug. 7, 1927) (on file in the Library of Congress).

469 Id. 
There is nothing to do but just keep at it, employ more detectives, if you need them, and after a while you will begin to get the thread and then you will have a collection of crimes with convictions that will break the thing up, but it needs hard work and the closest investigation." 470

In July 1927, Taft complained to Charles that one of the problems with prohibition enforcement was that Congress had underfunded the Treasury Department so that there were too few agents to enforce the federal laws. ${ }^{471}$ In a matter unrelated to bootlegging or Ohio but contemporaneous with his discussion of Ohio's law enforcement problems, in this same letter to Charles, Taft criticized noted defense counsel Clarence Darrow, as well as advocates to abolish the death penalty. ${ }^{472}$

Although Charles believed that Tumey was so popular that it would pay political dividends, it did not. He became well known for prosecuting George Remus, a Cincinnati bootlegger who possessed political power in the state and had murdered his own wife. ${ }^{473}$ However, a jury found Remus not guilty because of temporary insanity, and this harmed Charles' reputation. ${ }^{474}$ On July 25, 1928, Taft informed Sutherland:

[M]y son Charlie, the one who tried the Remus case, is running for office again and has a primary on the 14th of August. He has a very decided opposition, because the primary involves a charter or reform ticket and the regular ticket. I have felt considerable doubt as to his success. ${ }^{475}$

470 Letter from William Howard Taft, Chief Justice, U.S. Supreme Court, to Charles P. Taft, son of William Howard Taft (Aug. 7, 1927) (on file in the Library of Congress).

471 Letter from William Howard Taft, Chief Justice, U.S. Supreme Court, to Charles P. Taft, son of William Howard Taft (July 9, 1927) (on file in the Library of Congress).

472 Id. Taft's letter read in part:

I don't agree with the opponents of capital punishment at all. I think that those who commit crimes of violence in robbery are directly affected by the fear of capital punishment, and that it leaves the public helpless to abolish that as the extreme penalty... This man Darrow, who came very near being convicted of suborning perjury, is a great advocate of the abolition of the death penalty. I can not understand what the vogue is which makes him so popular a lecturer. One can understand why he is opposed to capital punishment, because it is his business to oppose it. I think the escape of those two young Jews who tortured that other young Jew to death is one of the greatest miscarriages of justice that we have had, in that it did not result in their execution.

Id. In this letter, Taft was referring to the Leopold and Loeb trial in Chicago.

473 CoOK, supra note 284, at 130-38.

474 Id. at $167-69$.

475 Letter from William Howard Taft, Chief Justice, U.S. Supreme Court, to George Sutherland, Assoc. Justice, U.S. Supreme Court (July 25, 1928) (on file in the Library of Congress). 
Charles failed in his efforts to be reelected and left electoral politics for a decade. ${ }^{476}$ He would, however, be elected as Cincinnati's mayor and be active in state politics. ${ }^{477}$

On March 8, 1927, the Cincinnati Enquirer reported that the Ohio legislature praised Taft and Cincinnati's city government feted Struble as a local hero. ${ }^{478}$ Struble, for his part, claimed the Court's decision was a "rebirth of liberty." ${ }^{479}$ The same day, the Chicago Tribune in a headline, which read "Village Mayor Loses Rum Fine Fee," reported that the Court's "opinion is considered of unusual importance as it may be interpreted to affect fee officers all over the country." 480 The newspaper also noted that Taft was from the same county in which the appeal arose. ${ }^{481}$ The Baltimore Sun noted, under a headline titled "Fee Splitting held Illegal by Court," that Maryland's traffic enforcement laws would have to change because the county magistrates who served over traffic ordnance courts earned their salaries by convictions. ${ }^{42}$ Given the laudatory reporting, one might have thought that Taft considered Tumey as the Court's "final say" on the matter of recusal and disqualification of judges. However, this was not the case. Within a year, the Court accepted an appeal and issued a decision that provided clarity to Tumey's reach regarding challenges based on pecuniary interest. ${ }^{483}$ Just as in Tumey, the new appeal arose from a liquor court conviction in Ohio. ${ }^{484}$ The Court in Dugan v. Ohio determined that the mayor of the city of Xenia was not required to recuse himself from the town's liquor court proceedings because his salary was generically based on the township's ability to raise revenue through a variety of means, including the collection of fines. ${ }^{485}$ The mayor's salary originated from a general fund based on monies accumulated through general fines, but the salary remained the same whether a defendant was acquitted or convicted. ${ }^{486}$ In a brief unanimous decision, the Court held that where a judicial officer is paid a regular salary through a general fund, there is no direct pecuniary interest in the outcome of trials; therefore, the judge is assumed to be impartial. ${ }^{487}$

476 Joseph Treaster, Charles P. Taft, Former Mayor of Cincinnati, N.Y. Times (June 25, 1983), http://www.nytimes.com/1983/06/25/obituaries/charles-p-taft-former-mayor-ofcincinnati.html.

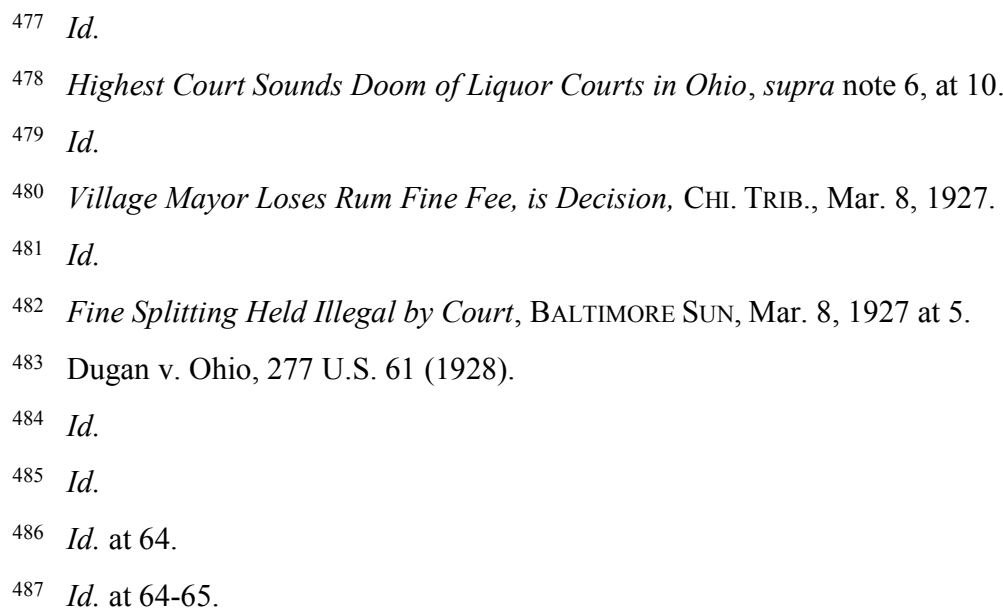




\section{CONCLUSION: CONTEMPORARY USE OF THE DECISION AND AN ARGUMENT FOR INCORPORATING JUDICIAL INTENT IN THE FUTURE}

In a 2007 law review article referencing Tumey, a federal judge observed, "One wonders how coincidental it was, but in 1927-just three years after the ABA adopted its Canons - Chief Justice Taft authored a seminal opinion for the United States Supreme Court." 488 The answer to this "wonder" is that there is no coincidence between the establishment of the 1924 Canons of Ethics and Tumey. From the time Taft became Chief Justice until his death on March 8, 1930, Taft shaped a jurisprudence emphasizing the importance of an impartial judiciary in all of the nation's courts.

There remains a question noted in the introduction: Can the legal history of Tumey, beginning with Chief Justice Taft's intent, apply to appeals beyond pecuniary interest considerations without undermining the integrity of the decision? Although the answer is yes, perspective on this question may be found in the Burger Court's deliberations on a 1972 pecuniary interest case. ${ }^{489}$ Notwithstanding Dugan, there were a number of unanswered questions regarding the full meaning of pecuniary interest, but it was not until over four decades passed that the Court would attempt to provide clarity to this meaning. ${ }^{490}$ In Ward v. Village of Monroeville, ${ }^{491}$ a majority of the Court interpreted Tumey as extending to salaries of judicial officers that relied on an indirect system of fine collections. That is, the city government of Monroeville, Ohio relied on the collection of traffic fines to fund roughly half of its operating budget. ${ }^{492}$ In an almost analogous replay forty-five years after Tumey, the Court determined that Ohio's system of traffic enforcement violated the Fourteenth Amendment's Due Process Clause. ${ }^{493}$ In an opinion authored by Justice William Brennan, the majority determined that because mayors were permitted to serve as inferior judges and the revenue raised from traffic enforcement that paid into a municipality's funds, in turn, paid a mayor's salary, the trial process could not withstand constitutional scrutiny. ${ }^{494}$ The majority did not cite to Tumey as a dispositive decision, but the justices acknowledged that the Ohio

488 Judge Peter W. Bowie, The Last 100 Years: An Era of Expanding Appearances, 48 S. TEX. L. Rev. 911, 918 (2007).

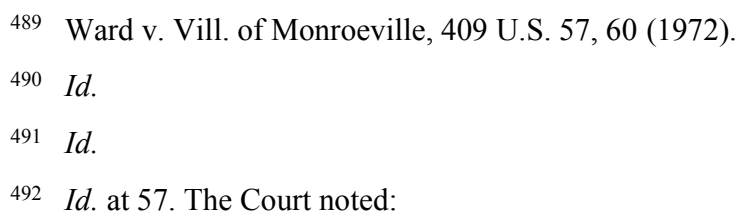

Thus, in 1964 this income contributed $\$ 23,589.50$ of total village revenues of $\$ 46,355.38$; in 1965 it was $\$ 18,508.95$ of $\$ 46,752.60$; in 1966 it was $\$ 16,085$ of $\$ 43,585.13$; in 1967 it was $\$ 20,060.65$ of $\$ 53,931.43$; and in 1968 it was $\$ 23,439.42$ of $\$ 52,995.95$. This revenue was of such importance to the village that when legislation threatened its loss, the village retained a management consultant for advice upon the problem.

Id.

$493 I d$. at 60.

494 Id. 
Supreme Court did so. ${ }^{495}$ The difference between Tumey and Ward was that in Ward the mayor's fixed salary was directly dependent on the municipality's maintenance of revenue from traffic ordnance violations, but unlike in Tumey, the mayor's salary could not fluctuate based on the numbers of convictions. ${ }^{496}$ The majority noted not only that Ohio's municipalities were generally dependent on traffic fines for the bulk of revenue, but also that it was a common practice for the municipal police to charge suspected offenders under their ordnances rather than under state law because once charged under state law, all revenue raised from fines went to the state's revenue coffers. ${ }^{497}$ The Ohio traffic statute enabled a defendant to challenge judicial officers for partiality on a case-by-case basis, but this statutory construct placed a burden of proof on individual defendants rather than providing a universal safeguard. ${ }^{498}$ Unlike in Tumey, neither party requested an oral argument to the Court although the Court ordered argument on October 17, 1972, in part, because the initial briefs were lamentably bereft of constitutional analysis. ${ }^{499} \mathrm{Ward}$ is a brief five-page decision for the majority, and the dissent, authored by Justice Byron White and joined by Justice William Rehnquist, consists of two paragraphs. ${ }^{500}$ White insisted that Tumey was "not controlling," because the mayor in Ward had "no direct financial stake in its outcome." 501

The brevity of the decision is not indicative of the Court's deliberations on the appeal or its use of Tumey. For instance, Justice Potter Stewart, an Ohioan, informed Brennan that the decision, like Tumey, would have considerable impact throughout the state. ${ }^{502}$ Moreover, Stewart argued that the decision should have enabled mayors to accept guilty pleas in instances where a fine was "fixed and mandatory." ${ }^{503}$ Originally, Chief Justice Warren Burger assigned the opinion to Brennan as a per curiam decision,

495 Id. at 59. Three Ohio justices dissented. Blackmun penned into his personal notes, "[T]he very fact that the Ohio Supreme Court split 4 to 3 is indicative to me of the closeness of the issues even among state judges."

496 See id. at 60; Tumey v. Ohio, 273 U.S. 510, 512 (1927).

497 Ward, 409 U.S. at 59-60.

498 Id. at 61.

499 See, e.g., Rehnquist, J., Draft Dissent, Ward v. Vill. Monroevill, 409 U.S. 57, (Jan. 19, 1972) (on file with the Papers of Justice Harry A. Blackmun in the Library of Congress).

500 Ward, 409 U.S. at 62 (White, J., dissenting).

501 Id. at 62 .

502 Letter from Potter Stewart, Associate Justice, U.S. Supreme Court, to William J. Brennan, Jr., Associate Justice, U.S. Supreme Court, (Oct. 27, 1972) (on file in the Library of Congress). Justice Stewart's letter to Justice Brennan resulted in Chief Justice Burger asking Justice Brennan to alter the decision to enable mayors to act in a clerical capacity such as the acceptance of a guilty plea. Letter from Warren E. Burger, Chief Justice, U.S. Supreme Court, to William J. Brennan, Associate Justice, U.S. Supreme Court, (Nov. 2, 1972) (on file in the Library of Congress).

503 Letter from Potter Stewart, Associate Justice, U.S. Supreme Court, to William J. Brennan, Jr., Associate Justice, U.S. Supreme Court, (Oct. 27, 1972) (on file in the Library of Congress). 
but because of the two dissenting justices, the decision listed the individual justices. ${ }^{504}$ Justice Blackmun's notes indicate that the majority debated the applicability of Tumey to Ward's appeal. ${ }^{505}$ Blackmun interpreted Tumey as standing for two propositions. First, that because Mayor A.R. Pugh directly and personally benefitted from finding Edward Tumey guilty, he was an interested party in the trial. ${ }^{506}$ Second, Pugh had a "personal interest in the fiscal soundness" of North College Hill, and "fines substantially contributed to that soundness." ${ }^{507}$ Blackmun acknowledged that Taft had led the Court in Tumey to the proposition that not all instances in which a mayor's executive function and judicial functions were intertwined resulted in a due process violation. ${ }^{508}$ This is why, Blackmun believed, that Taft had clarified Tumey with Dugan. However, because of "the sizeable dependency of the village upon its traffic fines and the mayor's responsibility for the village's good fiscal condition," Blackmun concluded the second proposition had been violated, and, therefore, Tumey should be extended to an area beyond a narrow definition of "direct pecuniary interest." 509

Initially Justice Rehnquist intended to separately concur. ${ }^{510}$ On October 30, he circulated a draft concurrence in which he conceded to the majority that the process of challenging the partiality of mayors and seeking recusals was flawed, but then, he insisted that traffic courts were not entitled to the same due process standards as criminal trials. ${ }^{511}$ However, on January 19, 1972, he dissented by arguing that the majority not only wrongly expanded Tumey, but he also claimed the majority "undermined tens of thousands of courts similar to that of Monroeville throughout the country." ${ }^{12} \mathrm{He}$ also complained that he could not "subscribe to the Court's action in summarily reversing the decision of the Supreme Court of Ohio without the further

504 See, e.g., per curiam draft (Jan. 10, 1972); Letter from William O. Douglas, Assoc. Justice, U.S. Supreme Court to William J. Brennan, Assoc. Justice, U.S. Supreme Court (Dec. 28, 1971) (on file with the Papers of Harry A. Blackmun in the Library of Congress); Letter from Potter Stewart, Assoc. Justice, U.S. Supreme Court to William J. Brennan, Assoc. Justice, U.S. Supreme Court (Jan. 3, 1972) (on file in the Library of Congress). On the original definition of "per curiam," meaning "an uncontroversial decision by an appellate court, see Per Curiam, BLACK's LAW DICTIONARY 1201 (9th ed. 2009). For a criticism of the overuse of per curiam decisions, see Ira P. Robbins, Hiding Behind the Cloak of Invisibility: The Supreme Court and Per Curiam Opinions, 86 Tul. L. REV, 1202-10 (2102).

505 Papers of Justice Harry A. Blackmun (on file in the Library of Congress).

506 Id.

507 Id.

508 Id.

509 Papers of Harry A. Blackmun (June 27, 1972) (on file in the Library of Congress).

510 Rehnquist, J., Draft Concurrence, Ward v. Vill. Monroevill, 409 U.S. 57 (Oct. 30, 1972) (on file in the Papers of Justice Harry A. Blackmun in the Library of Congress).

511 Id. Rehnquist's position on the limited application of due process to lesser courts was evident in Argerinsger v.Hamlin, 407 U.S. 25 (1972), in which he joined with Powell in a concurrence arguing that the right to counsel as determined in Gideon v. Wainright did not extend to all petty trials.

512 Rehnquist, J., Draft Dissent, Ward v. Vill. Monroevill, 409 U.S. 57 (Jan. 19, 1972) (on file with the Papers of Justice William J. Brennan in the Library of Congress) [hereinafter Rehnquist, Draft Dissent]. 
enlightenment that might come from oral argument and briefing." ${ }^{513}$ On November 1, 1972, Rehnquist opted to withdraw his dissent and joined with White. ${ }^{514}$ But, there is a feature of Rehnquist's January 19 draft that was later parroted by Justice Scalia in Caperton v. A.V. Massey. Among Rehnquist's stated reasons for dissent was a fear that the majority's decision would lead to an increase in challenges against judges and subsequent litigation. ${ }^{515}$ In spite of Rehnquist and White's opposition to the ultimate decision, the majority had crafted a decision that was consistent with Taft's views of the judiciary. That is, the Court in Ward found that the means of collecting revenues for the payment of judicial salaries undermined public confidence in the courts. ${ }^{516}$

Likewise, roughly two decades after Ward, a new majority followed the basic tenets of Taft's jurisprudence in its 2009 Caperton decision. ${ }^{517}$ In this decision, an appellant had donated not only to a candidate's campaign to unseat a sitting state court justice, but also had also sent $\$ 2.5$ million to a political action group that campaigned for the judicial challenger, Brent Benjamin. ${ }^{518}$ Justice Benjamin succeeded in his campaign to unseat a sitting state justice. ${ }^{519}$ While there is no evidence Justice Benjamin financially benefitted from the decision in the case, the Court's majority concluded that the donation required a judicial disqualification because of the appearance of a connection between Justice Benjamin and the appellant. ${ }^{520} \mathrm{In}$ particular, the donation to the election occurred after an adverse trial court decision and during the pendency of the appeal. ${ }^{521}$ The fact that the winning party in the case had a $\$ 50$ million verdict overturned in the favor of the party that donated to Justice Benjamin gave an appearance that one of the justices on the state court had been

513 Id.

514 Letter from William Howard Rehnquist, Chief Justice, U.S. Supreme Court, to Byron R. White, Assoc. Justice, U.S. Supreme Court (Nov. 1, 1972) (on file in the Library of Congress); Letter from William H. Rehnquist, Chief Justice, U.S. Supreme Court, to Warren E. Burger, Assoc. Justice, U.S. Supreme Court (Nov. 1, 1954) (on file in the Library of Congress).

515 Rehnquist, Draft Dissent, supra note 512. Rehnquist's phrase, "Thus the Court admonishes us that traffic judges, like Caesar's wife, must be above suspicion; however commendable this may be as a moral principle, both its generality and vagueness as a constitutional command cannot help but spawn litigation. Id. For comparison, see Caperton v. AT Massey Coal Co Inc., 556 U.S. 868 (2009) (Scalia J., dissenting). Justice Scalia claimed:

The Court's opinion will reinforce that perception, adding to the vast arsenal of lawyerly gambits what will come to be known as the Caperton claim. The facts relevant to adjudicating it will have to be litigated - and likewise the law governing it, which will be indeterminate for years to come, if not forever. Many billable hours will be spent in poring through volumes of campaign finance reports, and many more in contesting nonrecusal decisions through every available means.

Id.

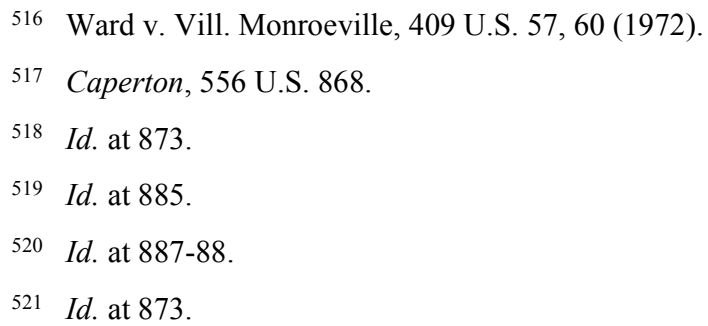


"bought." 522 Then, the majority concluded that the appearance of a "bought vote" undermined the public's belief in a fair tribunal. ${ }^{523}$ Given Taft's efforts to reform the judiciary as an underlying feature of Tumey, the majority's use of the decision in appeals arising from financial transactions comport with Taft's intent underlying the decision.

A second, and concededly more theoretical arena, involves Tumey's application to restrictions on judicial behavior. Led by Scalia, the majority's placement of the First Amendment over judicial efficacy in Minnesota $v$. White provides an example of a departure from Taft's intent. ${ }^{524}$ Coupling Taft's concurrence in Hecht, in which he acknowledged only a limited right of criticism against judges, with Tumey, it is probable that Taft would not have opposed a limited speech restriction on judicial campaigns. Moreover, while it is true that Taft never embraced the Brandeis/Holmes jurisprudence on free speech, he believed that public confidence in the judiciary was a key goal for the nation's courts. It is clear that in analyzing Cooke alongside of Tumey, he insisted on significant restraints on judicial temptations, or at least the appearance of such. While Taft would have considered general criticism of the judiciary to be fair play, he also, based on his experience with Landis, might have found it permissible to limit judicial speech. This may be one reason why he placed the following line in the decision:

[E]very procedure which would offer a possible temptation to the average man as a judge to forget the burden of proof required to convict the defendant, or which might lead him not to hold the balance nice, clear and true between the State and the accused, denies the latter due process of law. ${ }^{525}$

In the recent Williams $v$. Pennsylvania ${ }^{526}$ decision, the majority held that a sitting state supreme court justice who, while serving as a prosecuting attorney, supervised prosecutors in a death penalty case almost thirty years earlier, had a duty to recuse himself from an appeal arising out of the conviction in that case. The majority, led by Justice Kennedy, determined that because the state supreme court justice took a significant part in one aspect of the death penalty trial, there was not only an unacceptable risk of actual bias, but also a risk that "endangered the appearance of neutrality." 527 Although the majority only cited Tumey once, the decision nonetheless embraced Taft's intent underlying the application of Tumey to a broader use regarding disqualification. ${ }^{528}$

The courts should extend a greater use of Tumey as it applies to the nexus between disqualification and recusal on the one side and maintaining a public, rather than a theoretical, conception of judicial integrity on the other. This argument, like Taft's

\footnotetext{
522 See, e.g., Jeffrey Stempel, Impeach Brent Benjamin Now? Giving Adequate Attentions to Judicial Impartiality, 47 SAN DiEGO L. REV 1, 17 (2010).

523 Id. at 61 .

524 Minnesota v. White, 536 U.S. 765, 782 (2002).

525 Tumey v. Ohio, 273 U.S. 510, 532 (1927).

526 Williams v. Pennsylvania, 136 S. Ct. 1899 (2016).

527 Id. at 1908.

528 Id. at 1909.
} 
jurisprudence, is not based on any appeal for judicial activism or the extension of a so-called "progressive jurisprudence." Rather, it is in the application of Taft's conservative intent underlying Tumey to the present issues of indirect pecuniary interest, the interest of a donor, and the issues of campaign speech, which "opens the door" to the decision's extended application in disqualification and recusal appeals. 